\title{
Designating Appropriate Areas for Determining Potential Rainwater Harvesting in Arid Region Using a GIS-based Multi-criteria Decision Analysis
}

\author{
Mohamed Abd-el-Kader \\ King Saud University \\ Ahmed Elfeky ( $\square$ aelfeky@ksu.edu.sa ) \\ King Saud University \\ Mohamed Saber \\ Kyoto Daigaku - Uji Campus \\ Maged AlHarbi \\ King Saud University \\ abed Alataway \\ King Saud University
}

\section{Research Article}

Keywords: geographic information system, remote sensing, multi criteria evaluation, analytic hierarchy process, flash flood hazard, rainwater harvesting

Posted Date: November 15th, 2021

DOI: https://doi.org/10.21203/rs.3.rs-901829/v1

License: (c) (1) This work is licensed under a Creative Commons Attribution 4.0 International License. Read Full License 


\section{Abstract}

Flash floods are highly devastating, however there is no effective management for their water in Saudi Arabia, therefore, it is crucial to adopt Rainfall Water Harvesting (RWH) techniques to mitigate the flash floods and manage the available water resources from the infrequent and rare rainfall storms. The goal of this study is to create a potential flood hazard map and a map of suitable locations for RWH in Wadi Nisah, Saudi Arabia for future water management and flood prevention plans and to identify potential areas for rainwater harvesting and dam construction for both a flood mitigation and water harvesting. This research was carried out using a spatiotemporal distributed model based on multi-criteria decision analysis by combining Geographic Information System (GIS), Remote Sensing (RS), and Multi-Criteria Decision-Making tools (MCDM). The flood hazard mapping criteria were elevation, drainage density, slope, direct runoff depth at 50 years return period, Topographic witness index, and Curve Number, according to the Multi-criteria decision analysis, while the criteria for RWH were Slope, Land cover, Stream order, Lineaments density, and Average of annual max-24hr Rainfall. The weight of each criteria was estimated based on Analytical Hierarchy Process (AHP). In multi-criteria decision analysis, $21.55 \%$ of the total area for Wadi Nisah was classified as extremely dangerous and dangerous; $65.29 \%$ of the total area was classified as moderate; and $13.15 \%$ of the total area was classified as safe and very safe in flash flood hazard classes. Only $15 \%$ of Wadi Nisah has a very high potentiality for RWH and $27.7 \%, 57.31 \%$ of the basin has a moderate and a low or extremely low potentiality of RWH, respectively. According to the developed RWH potentiality map, two possible dam sites were proposed. The maximum height of the proposed dams, which corresponded to the cross section of dam locations, ranged from 6.2 to 9 meters; the maximum width of dams ranged from 573.48 to 725 meters; the maximum storage capacity of reservoirs, which corresponded to the distribution of topographic conditions in the surrounding area, ranged from $3976104.499 \mathrm{~m}^{3}$ to $4328509.123 \mathrm{~m}^{3}$; and the maximum surface area of reservoirs ranged from $1268372.625 \mathrm{~m}^{2}$ to $1505825.676 .14 \mathrm{~m}^{2}$. These results are highly important for the decision makers for not only flash flood mitigation but also water management in the study area.

\section{Highlights}

1. The potentiality of using RS data and GIS tools together with and Multi-Criteria Decision-Making tools (MCDM) to assess the flood hazard.

2. In flash flood hazard classes, 21.55 percent of the entire area for Wadi Nisah was categorized as highly hazardous and dangerous; 65.29 percent of the total area was rated as moderate; and 13.15 percent of the total area was classified as safe and very safe.

3. Two prospective dam locations were presented based on the generated RWH potentiality map.

\section{Introduction}

Rainfall in Kingdom of Saudi Arabia (KSA) is infrequent and irregular; however, annual rainfall in most of $\mathrm{KSA}$ is $100 \mathrm{~mm}$ as an average, thus water management in the country is a major problem owing to 
limited water supplies and increasing climate change uncertainties (Almazroui et al., 2012). As a result, it is critical for Saudi authorities to employ Rainfall Water Harvesting (RWH) techniques in order to meet rising water demand, particularly in the agriculture sector, which consumes more than $80 \%$ of total annual water use. RWH is used to supplement surface and groundwater supplies in order to balance supply and demand in the face of changing meteorological circumstances (Singh et al. 2017). RWH techniques also play an important role to minimize the impact of flash flood hazard through catch rainfall water in the suitable location before flood events occur and collect them in industrial lakes or make the harvested water to be used directly or injected to groundwater storage (Abdulla 2020). As a result, RWH might be a valuable water supply resource. According to Murray and Ebi (2012), flash floods are produced by an unusually large quantity of rain falling in a short period of time or a large volume of water being released quickly from rivers or dams. RWH can be defined as collecting and using precipitation from a catchment surface area. It is deliberate collection and storage of rainwater or augmentation of ground water reservoir by man-made structures (Sivanappan 2006). There are numerous methods used for RWH that differ from region to region. The inhabitants of that region have a significant difficulty in determining optimum locations and appropriate water collecting technologies on a big scale (Hofkes, 1983). This current study introduces a more detailed plan for evaluating and developing new water resources in Saudi Arabia by applying water harvesting of the generated flash flood that will reduce the flood risk at the outlet of wadi Nisah study area (Sivanappan 2006). In addition, it could be used for recharging the ground water aquifers, which are basis for sustainable development using new integrated modeling techniques in central Saudi Arabia, such as Rainfall-Runoff modeling, Geographic information system (GIS), Remote Sensing (RS). Floods can help to recharge the subsurface alluvium aquifer. The amount of flood infiltration is a key source of groundwater refilling to unconfined aquifers in dry areas Surface dams and consecutive dikes might greatly enhance groundwater recharge (Sirdaş and Šen, 2007). They are nevertheless significant for local hydrology research since they refill aquifers and groundwater reservoirs (Bahat et al., 2009).

Rainwater harvesting refers to techniques for causing, collecting, and storing runoff from a variety of sources and for a variety of uses. The methods used depend heavily on local conditions, including wadi terraced beds (Evenari et al., 1971), micro-capture trees (Nat. Acad, Sci. 1974), sheet metal catching runoff (Chiarella and Beck, 1975; mickelson, 1975), rushing subsurface (Burdass, 1975; Agarwal, 1977; Smith, 1978), and storing runoff behind a dam (Burdass, 1975; Agarwal, 1977; Smith, 1978),). (Bowler and Turner, 1977; Myhrman et al., 1978).

There are case studies from many nations across the world that employed some of the approaches or methodologies for assessing flood hazard and identifying potential RWH locations in the region under investigation (Singh et al. 2017). The spatial multi-criteria assessment by Analytical Hierarchy (AHP), developed by Saaty, is one of the techniques to identifying flash flood catastrophe zones. It selects the required criterion through the parameter and incorporates qualitative and quantitative elements into the method (Saaty, 1987). The MCA technique has been widely used for the management of complicated issues and flood risk assessment (Wang et al., 2011; Rahaman et al., 2015).. For Multi-Criteria Decision Making, a variety of approaches have been presented. MCA techniques give a framework for identifying 
the parts of a complex decision issue, organizing the elements into a hierarchical structure, and studying the connections between the problem's components (Boroushaki and Malczewski, 2010; Zavadskas et al., 2014).

One of the best knowledges and most extensively used MCA methods is the analytical hierarchy process (AHP) established by Saaty (1980) (Yahaya et al., 2010; Orencio and Fujii, 2013). AHP is used for solving a variety of MCDM issues, with the pairwise comparison matrix for each examined criterion computing the weight (Yalcin, 2008; Cozannet et al., 2013; Orencio and Fujii, 2013; Pourghasemi et al., 2016). AHP assumes full grouping between various criteria and develops a linear model of additives. The peculiarity of AHP in many research allows to model uncertainty without compromising any assessment measure's subjectivity and objectivity. It is dependent on expert opinions, however, and might thus be vulnerable to cognitive constraints with uncertainty and subjectivity (Pourghasemi et al., 2016). Late in the course of several research, substantial emphasis was paid to the application of AHP in natural hazard evaluation (earthquakes and flood): (Savane et al., 2003; Yahaya et al., 2010; Cozannet et al., 2013; Orencio and Fujii, 2013; Saley et al., 2013; Nejad et al., 2015; Papaioannou et al., 2015; Chakraborty and Joshi, 2016; Pourghasemi et al., 2016).

AHP applications that use GIS have been utilized widely since the beginning of the 21 st century (Mardani et al., 2015). The integration of AHP and GIS provides an efficient and user-friendly solution to solve challenging problems, as it combines decision-making support with powerful data mass processing, viewing and mapping capabilities (Marinoni, 2004). As stated by Kahinda et al. (2008), the Food and Agriculture Organization of the United Nations (FAO) specified six major criteria for selecting RWH sites: climate, hydrology, topography, agronomy, soils, and socio-economics. The most prevalent biophysical parameters utilized to identify potential RWH sites in arid and semi-arid environments were slope (83 \%), land use/cover (75\%), soil type (75\%), and rainfall (75\%) (56\%). The most often used socio-economic factors were distance to settlements (25 percent), distance to streams (15\%), distance to highways (15\%), and cost (8\%) (Ammar et al., 2016).

Structural measures are primarily concerned with the hydrological and hydraulic consequences of floods, which are often addressed by selecting the option that maximizes projected net benefits. Catchment-wide interventions, according to Colombo et al. (2002), are a type of structural measurement that can help minimize flash floods. Surface runoff and soil erosion can be reduced by catchment-wide interventions, and therefore flood peak can be reduced. However, they suggested some water control works structural as solutions contribute to flood reduction and protection. Some of these structures are used mainly as floodwater harvesting. The suggested structure according to Tingsanchali (2012) are Check Dams, Drainage ditches, and Bench-terraces.

Dams can be constructed for many purposes, which lead to a greater range of impacts and factors. In Western Iran, the study aimed at selecting an earth dam site utilizing an analysis hierarchy (AHP), a simple and adaptable approach for tackling multi-attribute (MADM) decision-making issues (Yasser et al., 2013). Minatour et al. (2015), which focused on the same research area, designed and implemented a 
decision making support system for the selection of dams, including the fuzzy AHP and the multi-criteria decision-making VIKOR method (MCDM).. Another study on dam site selection was conducted in Northwest Saudi Arabia in the same year, utilizing a combining of Remote Sensing (RS) methods and a Geographic Information System (GIS) (Abushandi and Alatawi, 2015). In the instance of Northwest Saudi Arabia, four factors were used to determine the optimum dam site location: catchment slope, land cover type, soil type, and soil infiltration rate (Abushandi and Alatawi, 2015). In the Western Iran case from 2013, 9 categories of criteria and 11 sub criteria are considered as most important attributes for identifying the earth dam site in this study. In particular, the criteria used in this study are the following: topographical conditions; economic development; wellness dam site; river flow system; annual output (water volume); reservoir volume; annual sediment volume; probable max flow; annual average evaporation; materiel and facilities accessible; total cost; water quality; damage to dam body and reservoir; possible dam breakage; environmental impact; social impact; political impact (Yasser et al., 2013).. While many of the research described above focused on the impacts on dam construction, other studies focused only on dam construction factors. For example, For example, a 2003 study proposed 13 indicators for selection of dam sites with a view to sustainable development, including a reservoir surface; reservoir retention time; flooded biomass; impounded river length; dry left-wing rivers; number of downstream river tributaries; probability of stratification of the reservoirs; useful life of the reservoir; access to roads through the forest; People requiring to be resettled; vital natural areas; variety of fish species and endemism; and damaged cultural property (Ledec and Quintero, 2003). The main objective and novelty of this paper was to develop a Multi-Criteria Decision Making (MCDM) approach to map the flood hazard and the optimal site for Rainfall Water Harvesting (RWH) for positioning suitable sites for the construction of surface dams in wad Nisah. The second goal is identifying potential rainwater harvesting areas and recommending the optimum sites for building dams to store the harvested water in Wadi Nisah is quite important for the local society in wadi system where the water resources are very limited. Furthermore. The particular objectives were to integrate the raster layers of each criteria, a weighted summation based on the weights generated by pairwise comparison. Elevation, drainage density, Slope, Direct runoff depth at 50-year return period, Topographic witness index, and Curve Number were the hazard criteria for selecting RWH sites, while Slope, Land cover, Stream order, Lineaments density, and Average of annual max-24hr Rainfall were the non-hazard criteria. The RWH suitability map, study of the suitability map, drainage network, drainage outlet, Triangulated Irregular Network (TIN) produced from DEM, and profile graph based on DEM revealed two potential dam locations.

\section{Material And Methods}

\subsection{Study area and Climatic conditions}

The area of investigation lies between $23^{\circ} 30^{\prime}-24^{\circ} 30^{\prime} \mathrm{N}$ and $46^{\circ} 00^{\prime \prime}-47^{\circ} 00^{\prime} \mathrm{E}$ latitudes as stated in fig. 1. The research zone is gradually sloping from $492 \mathrm{~m}$ in the low-lyers portion (southeast) to $1172 \mathrm{~m}$ in the south-west half, as a consequence of the Najd plateau and Tuaiq steep slopes. The research region is in the arid to semi-arid zone. The area under investigation has infrequent and variable rainfall, averaging 80 
to $120 \mathrm{~mm}$ yearly rainfall (Alsharhan et al., 2001). The study region has a continental climate, with temperatures that drop drastically in the winter and increase sharply in the summer. The typical winter temperature is 4 to 16 degrees Celsius, while the average summer temperature is 30 to 45 degrees Celsius. Summer solar radiation is high, ranging from 400 to $600 \mathrm{Cal} / \mathrm{cm} 2 /$ day, while winter solar radiation is low, ranging from 200 to $400 \mathrm{Cal} / \mathrm{cm}^{2} /$ day (Climate Atlas of Saudi Arabia, 1988). During the winter and spring, flooding can occur owing to localized heavy rainfall. The drainage from the catchment regions, which were mostly in the Arabian Shield hilly terrain, was the main cause of the flash floods.

\subsection{Mapping of flash floods hazard and the suitable potential locations for RWH}

The method for assessing the hazard of flash floods and determining the best site for a RWH differs by area and is based on techniques such as GIS, RS, and digitizing cartographic data. That is to say, this is a multi-criteria problem, and certain criterion had to be chosen in order to arrive at the optimal option. A multi-criteria decision analysis tool is a hierarchical analysis process (AHP) that enable users to target certain criterion and under criteria when weights are allocated. This technique is essential since another structure might produce a different final grade (Estoque and Murayama, 2010). The AHP-structure for flash flood risk mapping and suitable RFH-mapping regions as illustrated in Fig.2 was utilized throughout this investigation.

The AHP procedure for mapping involves the following main steps:

Table 1 Nine-point intensity of importance scale

Intensity of Definition Description
importance

$$
1
$$

3

5

7

$7 \quad$ Very strong more important

Equally important

Moderately more important

Strongly more important

Two factors contribute equally to the objective.

Experience and judgment slightly favor one over the other.

Experience and judgment strongly favor one over the other.

Experience and judgment very strongly favor one over the

Other. Its importance is demonstrated in practice.

9

Extremely more important

$2,4,6,8$

Intermediate values
The evidence favoring one over the other is of the highest

Possible validity.

When compromise was needed. 


\section{- Step (1): Criteria selection;}

According to several researches, such as Ouma and Tateishi (2014) and Xiao et al. (2016), we chose the criteria for assessing flash flood hazard and appropriate RWH site. Elevation, Slope, Curve number, Topographic witness index, direct runoff depth at 50-year return period, and Drainage density cell to cell, raster data were chosen as a criterion for flash flood hazard. Slope, Land cover, Stream order, Lineaments density, and Average of annual max-24-hr Rainfall cell-to-cell raster data were used to determine a suitable area for RWH. These criteria, also known as decision factors, are found in the level two of the AHP.

\section{- Step (2): Reclassify the selected criteria;}

The criterion data was categorized into a few different categories. According to the amount of flash hazard for flash flood criteria or the level of appropriateness for RWH for acceptable RWH criteria, each class was assigned a specific rank. These levels were referred to as Alternatives or Decision sub-factors, and they were found at AHP level three.

\section{- Step (3): Specification of weights for each criterion;}

In this step, the relative importance of each of the two criteria was established in this stage based on the majority of expert opinions, end user feedback, and comparable prior research such as Kazakis et al. (2015), Papaioannou et al. (2015), and Ouma and Tateishi (2014). The intensity of this importance was taken from table 1. By determination of intensity of importance for each criterion, we compared between criteria and developed the pair wise comparison diagonal matrix as shown at table 2 for flash flood hazard criteria and table 3 for suitable location of RWH criteria.

Table 2 Comparison Matrix for criteria of flash flood hazard

\begin{tabular}{lllllll} 
Criteria & Runoff depth & $\begin{array}{l}\text { Drainage } \\
\text { density }\end{array}$ & Elevation & Slope & TWI & CN \\
\hline Runoff depth & 1 & 2 & 3 & 1 & $1 / 3$ & $1 / 2$ \\
\hline $\begin{array}{l}\text { Drainage } \\
\text { density }\end{array}$ & $1 / 2$ & 1 & 1 & 1 & $1 / 5$ & $1 / 3$ \\
\hline Elevation & $1 / 3$ & 1 & 1 & $1 / 2$ & $1 / 4$ & $1 / 3$ \\
\hline Slope & 1 & 2 & 2 & 1 & $1 / 2$ & 2 \\
\hline TWI & 3 & 5 & 4 & 2 & 1 & 1 \\
\hline CN & 2 & 3 & 3 & $1 / 2$ & 2 & 1 \\
\hline Total & 7.833333333 & 14 & 14 & 6 & 4.28333333 & 5.16666667
\end{tabular}

Table 3 Comparison Matrix for criteria of suitable locations of RWH 


$\begin{array}{llll}\text { Criteria } & \text { Rainfall Land cover } \quad \text { Slope } & \begin{array}{l}\text { Stream } \\ \text { order }\end{array} & \begin{array}{l}\text { Lineaments } \\ \text { density }\end{array}\end{array}$

\begin{tabular}{llllll}
\hline Rainfall & 1 & 1 & $1 / 3$ & 3 & 3 \\
\hline Land cover & 1 & 1 & $1 / 3$ & 5 & 3 \\
\hline Slope & 3 & 3 & 1 & 7 & 5 \\
\hline Stream order & $1 / 3$ & $1 / 5$ & $1 / 7$ & 1 & 1 \\
\hline $\begin{array}{l}\text { Lineaments } \\
\text { density }\end{array}$ & $1 / 3$ & $1 / 3$ & $1 / 5$ & 1 & 1 \\
\hline Total & 5.666666667 & 5.533333333 & 2.00952381 & 17 & 13
\end{tabular}

Then, the relative weights of these criteria were then calculated by normalizing any rows and columns for pairwise comparison diagonal matrices, which meant dividing each element in every column by the total of that column at a new normalized matrix, and finding the Eigen vectors of these matrices as shown in Appendix Table A1 and A2, which were computed by taking the average of each row values in the normalizing $\mathrm{m}$. Each criteria's weight values are equal to the Eigen vector of the normalizing matrices.

Appendix Table A3 and A4 summarized all of the preceding three steps. The weights for each criterion were specified using the pairwise comparison matrix. To generate the best fit to the weight set, the main eigenvector of the pairwise comparison matrix was determined. The priorities were represented by weight values, which were absolute integers between zero and one. It indicated that the weights sum to one when using a weighted linear combination. Appendix Table A3 shows a summary of the flood causative factors or variables development, including the numerous components, their relative weights, and how they were ordered in terms of their effect on flood occurrences in the research region. The sub-factors $(J)$ in Appendix Table A3 and A4are the ranges of the decision factor (i) that contribute to the decision ranking values. Appendix Table A3 and A4 illustrate how the three-level hierarchical structure was deconstructed and how ranking decisions were made for future flash flood hazard mapping and RWH mapping appropriate locations.

\section{- Step (4): Evaluation the weights of each criteria;}

We have examined and combined RWH cells in the vicinity of drainage networks at acceptable locations with high relative suitability. If the slope creates a cell that's insufficient, check the regional TIN and profile diagram for usage at a dam location. For further selection, a $20-\mathrm{km}$ buffer layer was employed. Dams have been compared for $20 \mathrm{~km}$ till just one spot has been discovered in a $20 \mathrm{~km}$ buffer zone. Figure 4 shows how the dam site is selected;

$\mathrm{CR}=\frac{\mathrm{CI}}{\mathrm{RI}}$ 
Were $\mathrm{CR}$ is a Consistency ratio, $\mathrm{Cl}$ is a consistency index and $\mathrm{RI}$ is a Random index. The consistency index $(\mathrm{Cl})$ is defined as a factor which measure consistency of the diagonal comparison matrices. The following equation was used to find it;

$$
\mathrm{CI}=\frac{\lambda_{\max }-\mathrm{N}}{\mathrm{N}-1}
$$

Where $\lambda_{\max }$ is a largest eigenvalue of the comparison matrices and $\mathrm{N}$ is the dimension of the diagonal comparison matrices.

The Random index (RI) was obtained from the following table 4 according to Saaty (1990).

Table 4 Random index values for each number of criteria

\begin{tabular}{lllllllllll}
$\mathbf{N}$ & 1 & 2 & 3 & 4 & 5 & 6 & 7 & 8 & 9 & 10 \\
\hline $\mathbf{R I}$ & 0 & 0 & 0.85 & 0.9 & 1.12 & 1.24 & 1.32 & 1.41 & 1.45 & 1.49
\end{tabular}

In this step, the AHP-GIS multi criteria model was developed by overlaying the classified weighted raster data of criteria, which obtained from previous steps with a weighted linear combination using raster calculator analyst tool in ArcMap. Then the overlay final maps were divided to five Classes according to the weighted linear combination method using the following equation, and implied that the determined weights of criteria were acceptable.

\section{- Step (5): Mapping for flash flood hazard and suitable potential locations for RWH.}

The AHP-GIS multi criteria model was created in this phase by utilizing the raster calculator analyst tool in ArcMap to overlay the categorized weighted raster data of criteria collected in previous steps with a weighted linear combination. The overlay final maps were then separated into five classes using the weighted linear combination approach and the equation below:

$$
\mathrm{LC}=\frac{1}{\mathrm{n}} \sum_{\mathrm{i}=1}^{\mathrm{n}} \mathrm{D}_{\mathrm{i}} \mathrm{W}_{\mathrm{i}}
$$

Where LC is linear combination; $\mathrm{Di}$ is decision parameter; $\mathrm{W}_{\mathrm{i}}$ is AHP weight criteria; $\mathrm{n}$ is numbers of Criteria.

As a result of the LC, the final flash flood hazard map was reclassified into five new classes. These classes were extremely risky, risky, moderately risky, safe, and very safe. In addition, based on its LC, the Suitable sites for RWH final map was categorized into five new classes. These classes were excellent, very good, moderate, poor and unsuitable. 


\subsection{Methodology of flash flood mitigation}

Following the evaluation of floods, the second phase of flood control is reducing flood hazard. As a result, in this section of the research, we demonstrated one technique of reducing flood risks, namely the construction of dams, which is dependent on two key components. First, determine potential dam building sites. Second, create dam profiles to determine their storage capacity.

\subsubsection{Choose possible dam sites}

According to Yasser et al. (2013), The research area's prospective dam sites were selected using an integrated interpretation of the rainfall harvesting potential layer map, drainage stream layer map, Triangulated Irregular Network (TIN) obtained from DEM, and profile graph based on contour lines layer map generated from DEM. We have assessed RWH suitability cells in the vicinity of drainage networks with high relative suitability and mixed them strongly at appropriate locations. If the slope generates a cell that is inadequate, examine the regional TIN and profile diagram to see if this cell should be used at a dam site. A 20-km buffer layer of possible dam sites was used for further selection. Dams were compared around 20 kilometers from each other until only one place was found in a buffer zone of 20 kilometers. Figure 4 illustrates the method for selecting the dam site.

\subsubsection{Profile of proposed dams' sites}

A 1-meter interval contour layer was produced using DEM for each suggested potential dam, and the base height was chosen based on the dam's elevation. The Triangulated Irregular Network (TIN) and a 1-meter interval contour line layer are utilized to generate interpolation lines, which are essential to get cross section profiles and compute reservoir volume. As a result, dam heights were measured at 1-meter intervals.. Furthermore a 1-meter interval contour layer was constructed to calculate the dam height at a maximum reservoir capacity if the height of the dam did not grow owing to a potential catchment limit leakage. The storage capacity and the surface of the reservoir may be estimated with ArcGIS 3D Analyst Tools if dam height, dam position and soil surface (TIN) are available. Figure 4 shows the framework of the profile processing.

\section{Results}

\subsection{Multi-criteria decision analysis for Wadi Nisah}

The AHP was used to map flash flood hazards and possible locations in the Wadi Nisah study area as a Multicriteria Decision Analysis Tool in this part. Meanwhile, the AHP-GIS tool was chosen as a flood and RWH distribution approach because the AHP-GIS tool calculates all of the criteria for each cellular spatial raster data in the area under study to produce a precise result with the final overlay mapping. AHP's possible depth of runoff over 50 years was one of the criteria utilized to derive the final flood danger 
map.. It was calculated cell-by-cell using the SCS-CN method by solving the weighted Curve Number, maximum soil moisture retention depth, and 50-years return period rainfall depth equations (Abdelkader et al. 2021) . As a result, the maximum possible soil moisture retention depth map was created cell-by-cell as shown in figure $(5 \mathrm{a}, \mathrm{b})$.

Similar to flood hazard mapping, RWH mapping in the Wadi Nisah study region is based on an average of annual max-24hr Rainfall depth as one of the AHP criteria for mapping the RWH. Therefore, it was created for each cell raster data using the Kriging geostatistics approach for historical rainfall data, as shown in figure $5 \mathrm{c}$.

\subsubsection{Flash flood hazard map}

The flash flood hazard map for the Wadi Nisah study region was created by overlaying for categorized maps of the criteria that were chosen in the AHP structure based on their flash flood hazard rating choice (table 4). As illustrated in Figure 6, these criteria were Elevation, Drainage Density, Slope, and Direct Runoff Depth at 50-Year Return Period, Topographic Witness Index, and Curve Number. Then, using the raster calculator tool in ArcMap to extract the final map of flash flood hazard, each of the criteria is given its proportionate weight according to table (5).

According to the weighted linear combination, this overlay final map of flash flood hazard was classified into five classes. As indicated in figure, these courses were very risky, dangerous, moderately dangerous, safe, and very safe. Figure 8 shows that the highly risky and dangerous classifications accounted for $21.55 \%$. These are places in the settled regions that are near to the main channel of stream order 7 and are typically at low altitudes. Nonetheless, the moderate hazard was $65.29 \%$ of the total area, while the safe and extremely safe classes accounted for $13.15 \%$.

When comparing the flood hazard map with the elevation map, all of the highly risky and dangerous areas were found to be in areas with lower elevations, with the majority of them being less than $642 \mathrm{~m}$. The negative correlation between elevation and precipitation contributes to this, although it is not the primary factor. The visual interpretation of flash hazard maps and comparison between flash hazard maps and slope maps has been shown to be significantly merged on the micro level, which is primarily due to the change of pathway, also substantially blended in the Wadi Nisah region of investigation.

The additional hazard and hazardous locations in the Flash Flood Risk map were created for each subbasin of Wadi Nisah utilizing ArcMap attribute table as shown in Table 5 for the comparison of flash floods among AHP analyzing and morphometric analysis.

Table 5 Distribution of the flood risk areas using AHP analysis in Wadi Nisah 


\begin{tabular}{llll}
$\begin{array}{l}\text { Sub-basin } \\
\text { No }\end{array}$ & $\begin{array}{l}\text { Area of sub-basin } \\
\left(\mathrm{Km}^{2}\right)\end{array}$ & $\begin{array}{l}\text { Area of extra dangerous and } \\
\text { dangerous }\left(\mathrm{Km}^{2}\right)\end{array}$ & $\begin{array}{l}\text { Percentage of dangerous } \\
\text { area }\end{array}$ \\
\hline 1 & 63.642204 & 1.750793844 & $2.75 \%$ \\
\hline 2 & 76.019228 & 5.245702604 & $6.90 \%$ \\
\hline 3 & 70.904 & 8.774722712 & $12.38 \%$ \\
\hline 4 & 45.20139 & 9.751508373 & $21.57 \%$ \\
\hline 5 & 110.219101 & 10.15561139 & $9.21 \%$ \\
\hline 6 & 354.069741 & 57.33556672 & $16.19 \%$ \\
\hline 7 & 19.091777 & 6.759039202 & $35.40 \%$ \\
\hline 8 & 152.274961 & 32.45256444 & $21.31 \%$ \\
\hline 9 & 35.119855 & 5.704522175 & $16.24 \%$ \\
\hline 10 & 150.02387 & 33.44672397 & $22.29 \%$ \\
\hline 11 & 159.113482 & 22.65867792 & $14.24 \%$ \\
\hline 12 & 21.704524 & 2.699974089 & $12.44 \%$ \\
\hline 13 & 38.840428 & 12.81438742 & $32.99 \%$ \\
\hline 14 & 849.996967 & 241.8957683 & $28.46 \%$ \\
\hline
\end{tabular}

Table 5 shows that the sub-basins no. $(7,13,14$, and 4$)$ have the highest percentages of risky regions for flood susceptibility based on AHP analysis, suggesting that AHP and morphometric analysis for flash flood hazard assessment in Wadi Nisah were mostly in accord.

\subsubsection{Rainfall harvesting map}

The AHP multi-criteria assessment analysis assisted in establishing general rainwater harvesting suitability regions. Excellent, very good, moderate, poor, and inappropriate appropriateness are five similar units that indicate possible water harvesting locations. The RWH map was created by overlaying for classified maps of the criteria that were picked in AHP structure according to their ranking decision of RWH appropriate areas, similar to the flood hazard map (table 5). As illustrated in figure 9 , these criteria include Slope, Land cover, Stream order, Lineaments density, and Average of annual max-24hr Rainfall cell-to-cell raster data. Then, using the raster calculator tool in ArcMap, each of the criteria is given its proportionate weight, as indicated in table (5) to produce the final map of prospective water harvesting sites, as shown in figure 10.

Some of the research area's northern and middle sections were judged to be appropriate for water harvesting, based on the flood hazard map. The northern zone is well defined by its steep slopes and extensive hydrological network. The primary locations identified as feasible water collection zones are 
located below $650 \mathrm{~m}$ in elevation and on slopes of less than 14 degrees. The primary locations identified as low and extremely low suitability zones are located in the southern part of the research area. These zones can be found at heights of more than $650 \mathrm{~m}$ and slopes of more than 28 degrees. Rainfall depth and slope had a greater effect than any other parameter on the zones categorized as low and very low suitable for water harvesting. According to the prospective sites map for water harvesting, the appropriate and high suitability regions comprise around $321.87 \mathrm{~km}^{2}$. (15\% of total area). As indicated in figure 10 below, the low and extremely low suitability zones cover around $1230.07 \mathrm{~km} 2$ ( $57.31 \%$ land), whereas the moderate suitability zone covers just $594.27 \mathrm{~km} 2$ (27.69\% area).

From the RWH final map in Wadi Nisah, it can be seen that all of the highest suitable areas for rainwater harvesting (excellent class) are located in the "dangerous class" on the hazard final map of flash flood, and vice versa, implying that flood-prone areas are not required to be valid for water harvesting, but must be identified to protect lives and plants.

\subsection{Suitability analysis for construction of dams in Wadi Nisah}

The prospect of dams being built to minimize flood risks and contribute to the harvesting of water arising from floods in Wadi Nisah was investigated in this section, based on the identification of dam sites, the development of dam profiles, and the storage of reservoir for these dams.

\subsubsection{Sites proposed for dams}

To choose appropriate dam locations, an integrated dataset consisted of a rainwater harvesting potential layer, drainage stream order layer, Triangulated Irregular Network

(TIN) produced from DEM, and profile graph based on DEM was utilized. As a consequence, two potential dam sites have been suggested. Figure 11 depicts the position of planned dams with a RWH layer, while table 6 lists coordinates of the proposed dams' locations.

Table 6 coordinates of proposed dams in Wadi Nisah

\begin{tabular}{llll} 
Dam No & & Longitude $(\mathrm{E})$ & Latitude $(\mathrm{N})$ \\
\hline Dam 1 & from & $46^{\circ} 31^{\prime} 7.1496^{\prime \prime}$ & $24^{\circ} 15^{\prime} 28.3104^{\prime \prime}$ \\
\cline { 2 - 4 } & to & $46^{\circ} 31^{\prime} 33.7476^{\prime \prime}$ & $24^{\circ} 15^{\prime} 9216^{\prime \prime}$ \\
\hline Dam 2 & from & $46^{\circ} 33^{\prime} 9.5652^{\prime \prime}$ & $24^{\circ} 20^{\prime} 48.2388^{\prime \prime}$ \\
\cline { 2 - 4 } & to & $46^{\circ} 33^{\prime} 16.8768^{\prime \prime}$ & $24^{\circ} 20^{\prime} 38.148^{\prime \prime}$
\end{tabular}

All dams are built in or near mountainous areas with good valley shapes and high precipitation and runoff values. Dam number (1), on the aspect of drainage order, is in the 7th order of drainage, whereas 
dam number (2) is in the 5th order. The following considerations are likely to explain why all proposed dam sites are placed in higher levels of drainage networks: first, when comparing proposed dam sites to slope maps, the two dams are located in low slope areas, which have a relatively high rank to water harvest in the RWH map. Second, when the proposed dam locations were compared to the stream order map, the greater degree of stream order was associated with a relatively high rank for water harvest in the RWH map and a high projected for surface runoff in the flash flood map. Third, data from the whole Wadi Nisah was processed as a single input during the creation of stream order layer data, resulting in a multimillion level variance of accumulation value. Furthermore, the flow accumulation model overlooks consumption of water during transit. The hydrograph curves at the dam sites were created using the SCS$\mathrm{CN}$ technique and the HEC-HMS model to aid in hydraulic design for planned dams, as illustrated in figure 12 (A and B). Appendix Table A4 and A5 were created to summarize the results of dam hydrologic models.

\subsubsection{Profile of proposed dams Profile}

Profiles of proposed dams depending on their location were created using DEM, Triangulated Irregular Network (TIN), and 1-meter interval contour layers. The dam profile includes the elevation of the dam, the height of the dam, the width of the dam, the elevation of the reservoir surface, the maximum storage capacity of the reservoir, the maximum surface area of the reservoir, and the catchment area..

There are three categories of dams, according to Robinson (2006): small dams, middle dams, and big dams. Only small and intermediate prospective dams for water harvesting were discovered in this study, as shown in table 7.

Table 7 Size classification of dams

\begin{tabular}{lll} 
Category & Storage $\left(\mathrm{m}^{3}\right)$ & Height (meter) \\
\hline Small dams & $<1,234,000$ and $\geq 61,600$ & $<12.5$ and $\geq 7.5$ \\
\hline Intermediate Dam & $\geq 1,234,000$ and $<61,675,000$ & $\geq 12.5$ and $<30.5$ \\
\hline Large Dam & $\geq 61,675,000$ & $\geq 30.5$
\end{tabular}

Figure 13 exhibits the multiple volumes of water that may be retained in Dam1's position as well as the dam's profile. It is located at from $46^{\circ} 31^{\prime} 7.1496^{\prime \prime} \mathrm{E}$ and $24^{\circ} 15^{\prime} 28.3104^{\prime \prime} \mathrm{N}$ to $46^{\circ} 31^{\prime} 33.7476^{\prime \prime} \mathrm{E}$ and $24^{\circ}$ $15^{\prime} 9216^{\prime \prime} \mathrm{N}$. The dam's elevation is $648 \mathrm{~m}$ above sea level. The dam stands 648 meters above sea level. Table 8 displays Dam 1's storage capacity at various heights. Dam 1 has a maximum height of $6.21 \mathrm{~m}, \mathrm{a}$ storage capacity of 4.32 million cubic meters measured from the drainage bed to the dam's top, and a surface area of $1.8 \mathrm{~km} 2$ measured from the drainage bed to the dam's top. According to table 8, Dam 1 was classified as a small dam. The catchment area of Dam 1 is about $1285.85 \mathrm{~km}^{2}$. In addition, the volume of runoff from the catchment of Dam 1 is about 29.35 million cubic meter at 100-years return period. 
Table 8 Characteristics of proposed Dam 1

\begin{tabular}{lllll}
$\begin{array}{l}\text { Elevation } \\
(\mathrm{m})\end{array}$ & $\begin{array}{l}\text { Dam height } \\
(\mathrm{m})\end{array}$ & $\begin{array}{l}\text { Dam width } \\
(\mathrm{m})\end{array}$ & Storage capacity $\left(\mathrm{m}^{3}\right)$ & Max surface area $\left(\mathrm{m}^{2}\right)$ \\
\hline 647.7899 & 0 & 0 & 0 & 0 \\
\hline 648 & 0.21 & 5 & 897.990314 & 12225.29292 \\
\hline 649 & 1.21 & 320 & 38780.70583 & 54314.64617 \\
\hline 650 & 2.21 & 505 & 215699.2552 & 251886.7453 \\
\hline 651 & 3.21 & 580 & 681616.3844 & 515899.4761 \\
\hline 652 & 4.21 & 655 & 1333528.876 & 701389.5395 \\
\hline 653 & 5.21 & 675 & 2608209.792 & 1358737.186 \\
\hline 654 & 6.21 & 725 & 4328509.123 & 1805825.676
\end{tabular}

Figure 14 shows the multiple volumes of water that may be held in Dam 2's position as well as the dam's profile. It is located at from $46^{\circ} 33^{\prime} 9.5652^{\prime \prime} \mathrm{E}$ and $24^{\circ} 20^{\prime} 48.2388^{\prime \prime} \mathrm{N}$ to $46^{\circ} 33^{\prime} 16.8768^{\prime \prime} \mathrm{E}$ and $24^{\circ} 20^{\prime}$ $38.148 " \mathrm{~N}$. The dam is at a height of 664.4 meters above sea level. Table 8 illustrates the storage capacity of Dam 2 at various heights. Dam 2 has a maximum height of 9 meters, a maximum storage capacity of 4 million cubic meters measured from the drainage bed to the top of the dam, and a maximum surface area of 1.268 square kilometers measured from the drainage bed to the top of the dam. Dam 2 was classed as a minor dam according to table 9 . The catchment area of Dam 2 is approximately $154.8 \mathrm{~km}^{2}$. Furthermore, during a 100-year return period, the volume of runoff from Dam 2's catchment is about 3.19 million cubic meters.

Table 9 Characteristics of proposed Dam 2 


\begin{tabular}{lllll} 
Elevation $(\mathrm{m})$ & $\begin{array}{l}\text { Dam height } \\
(\mathrm{m})\end{array}$ & $\begin{array}{l}\text { Dam width } \\
(\mathrm{m})\end{array}$ & $\begin{array}{l}\text { Storage capacity } \\
\left(\mathrm{m}^{3}\right)\end{array}$ & Max surface area $\left(\mathrm{m}^{2}\right)$ \\
\hline 664.3901978 & 0 & 0 & 0 & 0 \\
\hline 664.4803161 & 0.09 & 25 & 144.211507 & 1911.871687 \\
\hline 665.4803161 & 1 & 297.5 & 40900.93225 & 44301.88769 \\
\hline 666.4803161 & 2 & 377.5 & 90588.4336 & 54201.76447 \\
\hline 667.4803161 & 3 & 400 & 167112.3879 & 84347.85319 \\
\hline 668.4803161 & 4 & 425 & 257524.7908 & 96918.01217 \\
\hline 669.4803161 & 5 & 445 & 646700.3523 & 422114.5187 \\
\hline 670.4803161 & 6 & 472.5 & 1166220.089 & 553772.0419 \\
\hline 671.4803161 & 7 & 517.5 & 1876622.667 & 759731.7304 \\
\hline 672.4803161 & 8 & 547.5 & 2774328.069 & 947661.0919 \\
\hline 673.4803161 & 9 & 573.48 & 3976104.499 & 1268372.625
\end{tabular}

In general, existing data was used to identify an appropriate region for potential dam sites. Other variables, such as socioeconomic status, were not available for use in this study. Furthermore, the population distribution of the villages.

\section{Conclusion}

In arid regions, such as Saudi Arabia, the water scarcity is a critical issue due to increasing the water demand, however the water resources are limited with the rainfall events. Thus, water harvesting of flash floods in such regions is a must and essential for the local society. GIS software and satellite images are frequently utilized in quantitative analysis to assess flash flood hazard and drainage basin suitability for RWH because they can gather, process, and analyze huge data sets in a short amount of time. This research was carried out using a spatiotemporal distributed model based on multi-criteria decision analysis by combining Geographic Information System (GIS), Remote Sensing (RS), and Multi-Criteria Decision-Making tools (MCDM). The research included a multi-criteria decision making analysis (MCDM) in order to determine the potential hazards of Wadi Nisah in space and in time and assess the adequacy for RWH. Analysis of the flood risk and optimal RWH location was based on the Analytical Hierarchy Process. The flood hazard mapping criteria were elevation, drainage density, slope, direct runoff depth at 50 years return period, Topographic witness index, and Curve Number, according to the Multi-criteria decision analysis, while the criteria for RWH were Slope, Land cover, Stream order, Lineaments density, and Average of annual max-24hr Rainfall. The weight of each criteria was estimated based on Analytical Hierarchy Process (AHP). Also, elevation, drainage density, Slope, Direct runoff depth at 50-year return period, Topographic witness index, and Curve Number were the hazard criteria, whereas Slope, Land cover, Stream order, Lineaments density, and Average of annual max-24hr Rainfall were the RWH criteria. 
A weighted summation utilizing the weights produced by pairwise comparison was used to integrate the raster layers of all criterion. In terms of percentages, $21.55 \%$ of the entire area in Wadi Nisah was classified as highly hazardous and dangerous; $65.29 \%$ area was classified as moderate; and 13.15 percent of the total area was classified as safe and very safe in flash flood hazard classifications. Only $15 \%$ of Wadi Nisah has a very high potentiality for RWH and $27.7 \%, 57.31 \%$ of the basin has a moderate and a low or extremely low potentiality of RWH, respectively.

Besides the RWH suitability map, a suitability map analysis, a drainage network, a drainage outlet, a triangular DEM-based irregular system (TIN) and a DEM-based profiled graph showed two potential dam sites. A profile of each dam comprised a cross-section of the dam site, potential dam heights, potential dam widths, dam height, potential storage capacity, and reservoir surface with a dam, as well as a proposed dam sites were developed. All the dam locations in Wadi Nisah were planned in a low altitude area. The maximum height of dams, which corresponded to the cross section of dam locations, varied from $6.2 \mathrm{~m}$ to $9 \mathrm{~m}$; maximum width of dams varied from $573.48 \mathrm{~m}$ to $725 \mathrm{~m}$; the maximum storage capacity of reservoirs, corresponding to distribution of topographic conditions in surrounding area, varied from $3976104.499 \mathrm{~m}^{3}$ to $4328509.123 \mathrm{~m}^{3}$; the maximum surface area of reservoir varied from $1268372.625 \mathrm{~m}^{2}$ to $1805825.676 .14 \mathrm{~m}^{2}$.

However, the importance of this study and results as preliminary for sustainable flash flood management and water harvesting, especially for the local society and the results should be considered by the decision makers for further steps for better and secure water management in such water scarcity regions. One source of uncertainty in this study was the assessment on functions of preference value of criteria for measuring flash flood hazard and RWH in the Wadi Nisah area. The preference values for all of the criteria classes had linear functions, which were probably correct for some criteria but incorrect for others. Although the relative preference judgements within each criteria were based on previous research, the allocation weight value judgments were subjective and difficult to confirm in simple experiments. As a result, additional research into these judgements will be required for future research in the study location. Furthermore, high-resolution DEM data, such as $2.5 \mathrm{~m}$, should be collected since the topographic characteristics derived from DEM vary significantly with resolution.

\section{Declarations}

\section{Ethical approval}

The study doesn't require ethical approval because it did not include human participants or animals.

Informed consent "Informed consent wasn't obtained from all individual participants included in this paper because it did not include human participants or animals."

Consent to Publish "publish consent wasn't obtained from all individual participants included in this paper because it did not include human participants or animals." 


\section{Author contributions}

Conceptualization M M. A, AE. F; Methodology: M M. A, AE. Formal analysis: M M. A; Investigation: M M. A, AE. F; Writing - original draft; M M. A, M. S; writing - review \& editing M M. A, AE. F, M. S funding acquisition: M. A; A. A; AE. F, M. S; Resources; M. A; AE. F; Supervision; M. A; AE. F, M. S.

\section{Funding}

This project was financially supported by the Vice Deanship of Research Chairs at King Saud University, Saudi Arabia. Also, the authors thank the Deanship of Scientific Research and RSSU at King Saud University for their technical support.

\section{Disclosure of potential conflicts of interest}

The authors declare that they have no known competing financial interests or personal relationships that could have appeared to influence the work reported in this paper.

\section{Availability of data and materials}

The datasets generated during and/or analysed during the current study are available from the corresponding author on reasonable request.

\section{References}

Abdulla, F. 2020. Rainwater harvesting in Jordan: potential water saving, optimal tank sizing and economic analysis. Urban Water Journal, 17(5), 446-456.

https://doi.org/10.1080/1573062X.2019.1648530.

Abushandi E., Alatawi S. 2015 Dam site selection using remote sensing techniques and geographical information system to control flood events in Tabuk City. Hydrol. Current Res 6:189. DOI: 10.4172/21577587.1000189.

Abdelkader MM, Al-Amoud Al, El Alfy M, et al 2021 Assessment of flash flood hazard based on morphometric aspects and rainfall-runoff modeling in Wadi Nisah, central Saudi Arabia. Remote Sens Appl Soc Environ 23:100562. https://doi.org/10.1016/j.rsase.2021.100562.

Agarwal A. (1977) Coaxing the barren deserts back to life. New Scientist.

Almazroui M., Nazrul Islam M., Athar H., Jones P., Rahman M.A. 2012 Recent climate change in the Arabian Peninsula: annual rainfall and temperature analysis of Saudi Arabia for 1978-2009. International Journal of Climatology 32:953-966. https://doi.org/10.1002/joc.3446.

Alsharhan A., Rizk Z., Nairn A.E.M., Bakhit D., Alhajari S. 2001 Hydrogeology of an arid region: the Arabian Gulf and adjoining areas Elsevier. 
Ammar A., Riksen M., Ouessar M., Ritsema C. (2016) Identification of suitable sites for rainwater harvesting structures in arid and semi-arid regions: A review. International Soil and Water Conservation Research 4:108-120.

ArcGIS Desktop 9.3 help, ESRI,2009

(http://webhelp.esri.com/arcgisdesktop/9.2/index.cfmTopicName=Using\%20kriging, Accessed, September 2012.

Bahat Y., Grodek T., Lekach J., Morin E. 2009 Rainfall-runoff modeling in a small hyper-arid catchment. Journal of hydrology 373:204-217. https://doi.org/10.1016/j.jhydrol.2009.04.026.

Bojovic N., Milenkovic M. 2008 The best rail fleet mix problem. Operational Research 8:77-87. https://doi.org/10.1007/s12351-008-0012-8.

Boroushaki S., Malczewski J. 2010 Using the fuzzy majority approach for GIS-based multicriteria group decision-making. Computers \& Geosciences 36:302-312. https://doi.org/10.1016/j.cageo.2009.05.011.

Bowler D., Turner M. 1977 Water harvesting on a yellow-grey earth, Proceedings of the New Zealand grassland association. https://doi.org/10.33584/jnzg.1977.39.1482.

Chakraborty A., Joshi P. 2016 Mapping disaster vulnerability in India using analytical hierarchy process. Geomatics, Natural Hazards and Risk 7:308-325. https://doi.org/10.1080/19475705.2014.897656.

Chiarella J.V., Beck W.H. 1975 Water harvesting catchments on Indian lands in the Southwest. ARS W Agric Res Serv US Dep Agric.

Climate Atlas of Saudi Arabia 1988 Publication of Ministry of Agriculture and Water (now Ministry of Water and Electricity) in cooperation with the Saudi Arabian-United States Joint Commission on Economic Cooperation

Colombo A., Hervás J., Vetere Arellano A.L. 2002 Guidelines on flash flood prevention and mitigation, European Commission Joint Research Centre (JRC).

Cozannet G.L., Garcin M., Bulteau T., Mirgon C., Yates M., Méndez M., Baills A., Idier D., Oliveros C. 2013 An AHP-derived method for mapping the physical vulnerability of coastal areas at regional scales.

Natural Hazards and Earth System Sciences 13:1209-1227. https://doi.org/10.5194/nhess-13-1209-2013.

Estoque R.C., Murayama Y. 2010 Suitability analysis for beekeeping sites in La Union, Philippines, using GIS and multi-criteria evaluation techniques. Res. J. Appl. Sci 5:242-253.

DOI: 10.3923/rjasci.2010.242.253.

Evenari M., Shanan L., Tadmor N. 1971 The Negev. The challenge of a desert. The Negev. The challenge of a desert. 
Kahinda J.M., Lillie E., Taigbenu A., Taute M., Boroto R. 2008 Developing suitability maps for rainwater harvesting in South Africa. Physics and Chemistry of the Earth, Parts A/B/C 33:788-

799. https://doi.org/10.1016/j.pce.2008.06.047.

Kazakis N., Kougias I., Patsialis T. 2015 Assessment of flood hazard areas at a regional scale using an index-based approach and Analytical Hierarchy Process: Application in Rhodope-Evros region, Greece. Science of the Total Environment 538:555-563. https://doi.org/10.1016/j.scitotenv.2015.08.055.

Ledec G., Quintero J.D. 2003 Good dams and bad dams: Environmental criteria for site selection of hydroelectric projects. http://hdl.handle.net/10986/20226.

Mardani A., Jusoh A., MD Nor K., Khalifah Z., Zakwan N., Valipour A. 2015 Multiple criteria decisionmaking techniques and their applications-a review of the literature from 2000 to 2014. Economic Research-Ekonomska Istraživanja 28:516-571. https://doi.org/10.1080/1331677X.2015.1075139.

Minatour Y., Khazaie J., Ataei M., Javadi A. 2015 An integrated decision support system for dam site selection. Scientia Iranica. Transaction A, Civil Engineering 22:319.

Murray V., Ebi K.L. (2012) IPCC special report on managing the risks of extreme events and disasters to advance climate change adaptation (SREX), BMJ Publishing Group Ltd. http://dx.doi.org/10.1136/jech2012-201045.

Myhrman M., Cluff C., Putnam F. 1978 Rainfall-runoff relationships for a mountain watershed in Southern Arizona, Hydrology and water resources in Arizona and the southwest, Arizona-Nevada Academy of Science. http://hdl.handle.net/10150/301132.

Nejad A.R.V., Esmaeili S., Aghamohammadi H. 2015 Earthquake risk modeling using GIS for urban buildings, case study: Tehran municipality, district 3. Advances in Natural and Applied Sciences 9:3643. http://www.aensi.org/anas.html

Orencio P.M., Fujii M. (2013) A localized disaster-resilience index to assess coastal communities based on an analytic hierarchy process (AHP). International Journal of Disaster Risk Reduction 3:6275. https://doi.org/10.1016/j.ijdrr.2012.11.006.

Ouma Y.O., Tateishi R. (2014) Urban flood vulnerability and risk mapping using integrated multiparametric AHP and GIS: methodological overview and case study assessment. Water 6:15151545. https://doi.org/10.3390/w6061515.

Papaioannou G., Vasiliades L., Loukas A. (2015) Multi-criteria analysis framework for potential flood prone areas mapping. Water resources management 29:399-418. https://doi.org/10.1007/s11269-0140817-6.

Pourghasemi H.R., Beheshtirad M., Pradhan B. (2016) A comparative assessment of prediction capabilities of modified analytical hierarchy process (M-AHP) and Mamdani fuzzy logic models using 
Netcad-GIS for forest fire susceptibility mapping. Geomatics, Natural Hazards and Risk 7:861-885. https://doi.org/10.1080/19475705.2014.984247.

Rahaman S.A., Ajeez S.A., Aruchamy S., Jegankumar R. (2015) Prioritization of Sub Watershed Based on Morphometric Characteristics Using Fuzzy Analytical Hierarchy Process and Geographical Information System-A Study of Kallar Watershed, Tamil Nadu. Aquatic Procedia 4:1322-1330.

https://doi.org/10.1016/j.aqpro.2015.02.172.

Robinson, Jim, DCR Dam Safety Technical AdvisoryTable 1 Briefing, Department of Conservation and Recreation, Coserving Virginia's Natural and Recreational Resources, June 2006, USA. (http://www.dcr.virginia.gov/documents/dstbl1.pdf).

Saaty R.W. (1987) The analytic hierarchy process-what it is and how it is used. Mathematical modelling 9:161-176. https://doi.org/10.1016/0270-0255(87)90473-8.Saaty T.L. (1980) The analytic hierarchy process: planning, priority setting, resources allocation. New York: McGraw 281.

Saaty T.L. (1990) How to make a decision: the analytic hierarchy process. European journal of operational research 48:9-26.

Saley M., Danumah J., Sorokoby V., Kanohin F., Atcheremi D., Denean S., Kouame F., Djagoua V. (2013) Méthodologie pour la cartographie des zones vulnerables a l'inondation par systeme d'information géographique et analyse multicritère: application au bassin versant de la Davo a Sassandra (sud-ouest de la Cote d'Ivoire). Africa Geoscience Review 20:21-33.

Savane I., Coulibaly N., Soro N. (2003) Analyse multicritère spatiale pour l'identification de la vulnérabilité aux risques naturels d'Abobo (banlieue de la ville d'Abidjan, Côte d'Ivoire). Rev. Ivoir. Sci. Technol 4:94107.

Sivanappan, R. K. (2006, November). Rain water harvesting, conservation and management strategies for urban and rural sectors. In National Seminar on Rainwater Harvesting and Water Management (Vol. 11, No. 12, p. 1).

Singh, L. K., Jha, M. K., \& Chowdary, V. M. (2017). Multi-criteria analysis and GIS modeling for identifying prospective water harvesting and artificial recharge sites for sustainable water supply. Journal of Cleaner Production, 142, 1436-1456. https://doi.org/10.1016/j.jclepro.2016.11.163.

Sirdaş S., Şen Z. (2007) Determination of flash floods in western Arabian Peninsula. Journal of Hydrologic Engineering 12:676-681. DOI: 10.1061/(ASCE)1084-0699(2007)12:6(676).Tingsanchali T. (2012) Urban flood disaster management. Procedia engineering 32:25-37. https://doi.org/10.1016/j.proeng.2012.01.1233.

U.S. Department of Agriculture, Soil Conservation Service (1972). Hydrology. In "SCS National Engineering Handbook". Section 4. (U.S. Gov. Print. Office: Washington, D.C.). 
Wang Y., Li Z., Tang Z., Zeng G. (2011) A GIS-based spatial multi-criteria approach for flood risk assessment in the Dongting Lake Region, Hunan, Central China. Water resources management 25:34653484. https://doi.org/10.1007/s11269-011-9866-2.

Xiao Y., Yi S., Tang Z. (2016) GIS-based multi-criteria analysis method for flood risk assessment under urbanization, Geoinformatics, 2016 24th International Conference on, IEEE. pp. 1-5. DOI:

10.1109/GEOINFORMATICS.2016.7578963.

Yahaya S., Ahmad N., Abdalla R.F. (2010) Multicriteria analysis for flood vulnerable areas in HadejiaJama'are River basin, Nigeria. European Journal of Scientific Research 42:71-83.

Yasser M., Jahangir K., Mohmmad A. (2013) Earth dam site selection using the analytic hierarchy process (AHP): a case study in the west of Iran. Arabian Journal of Geosciences 6:3417-3426. DOI 10.1007/s12517-012-0602-x.

Zahedi F. (1986) The analytic hierarchy process a survey of the method and its applications. interfaces 16:96-108. https://doi.org/10.1287/inte.16.4.96.

Zavadskas E.K., Turskis Z., Kildienė S. (2014) State of art surveys of overviews on MCDM/MADM methods. Technological and economic development of economy 20:165-179. https://doi.org/10.3846/20294913.2014.892037.

\section{Appendix}

Appendix is not available with this version.

\section{Figures}




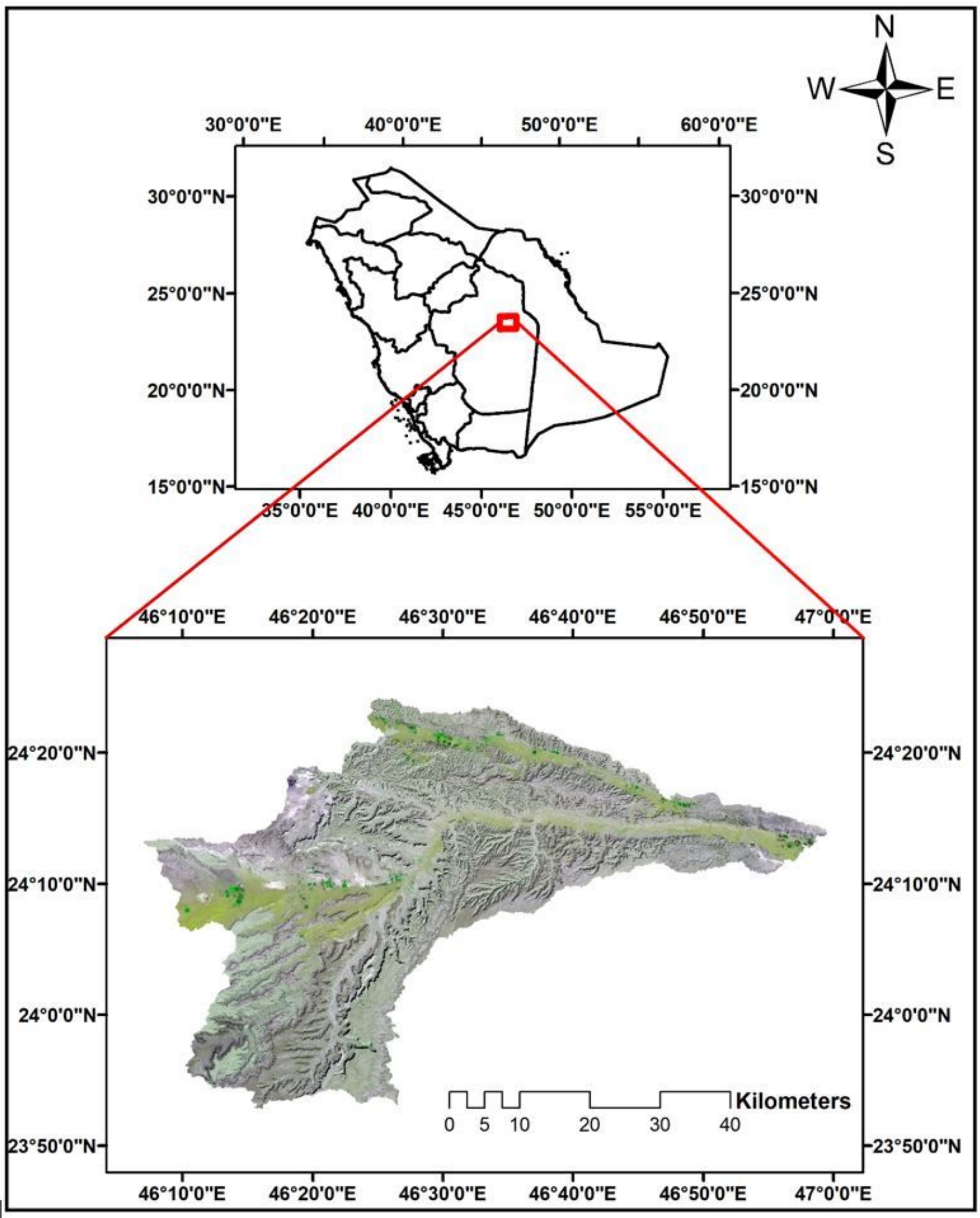

Figure 1

Location map of Wadi Nisah. 


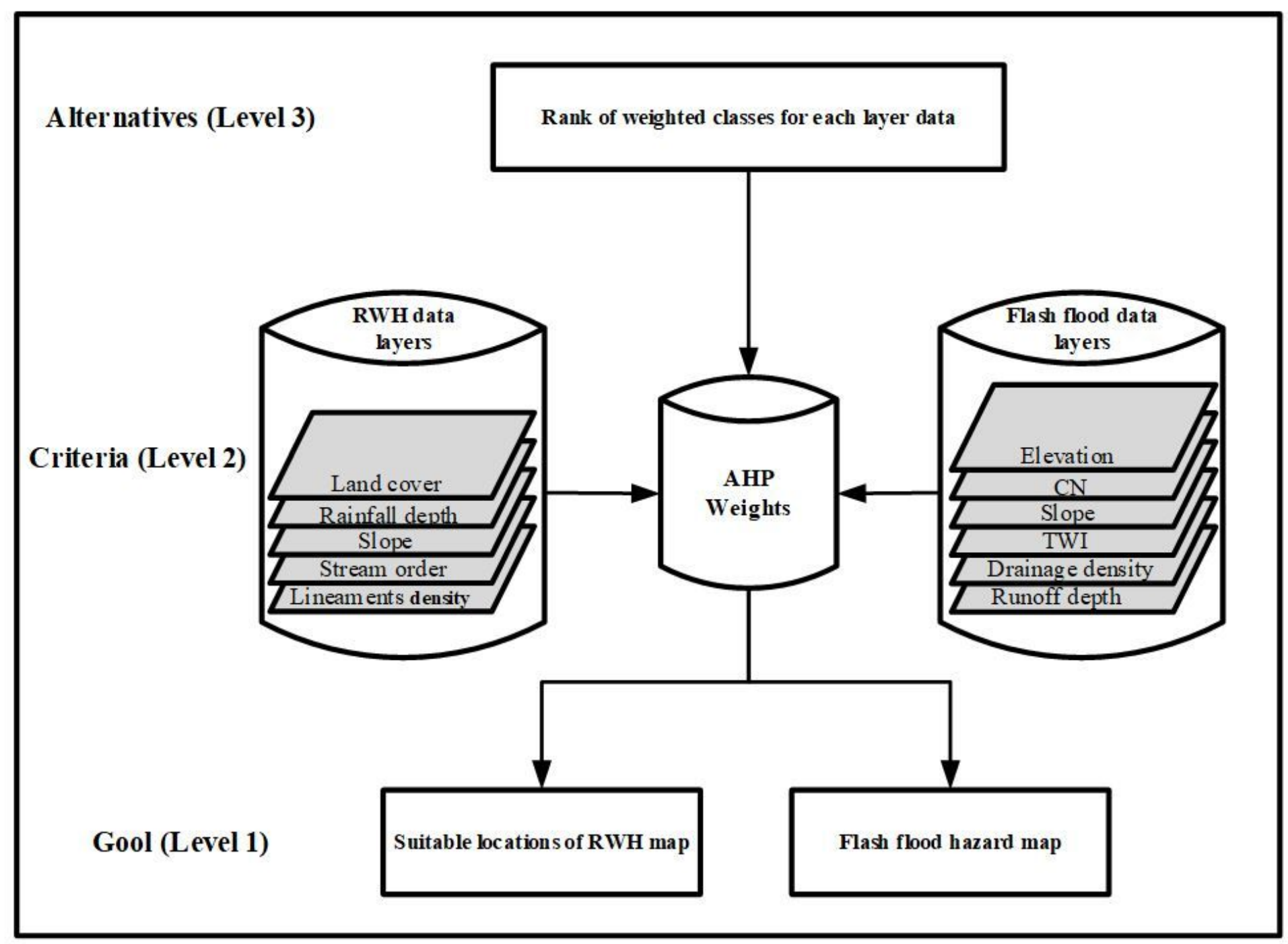

Figure 2

Flowchart of AHP method for flash flood hazard and suitable locations for RWH mapping 


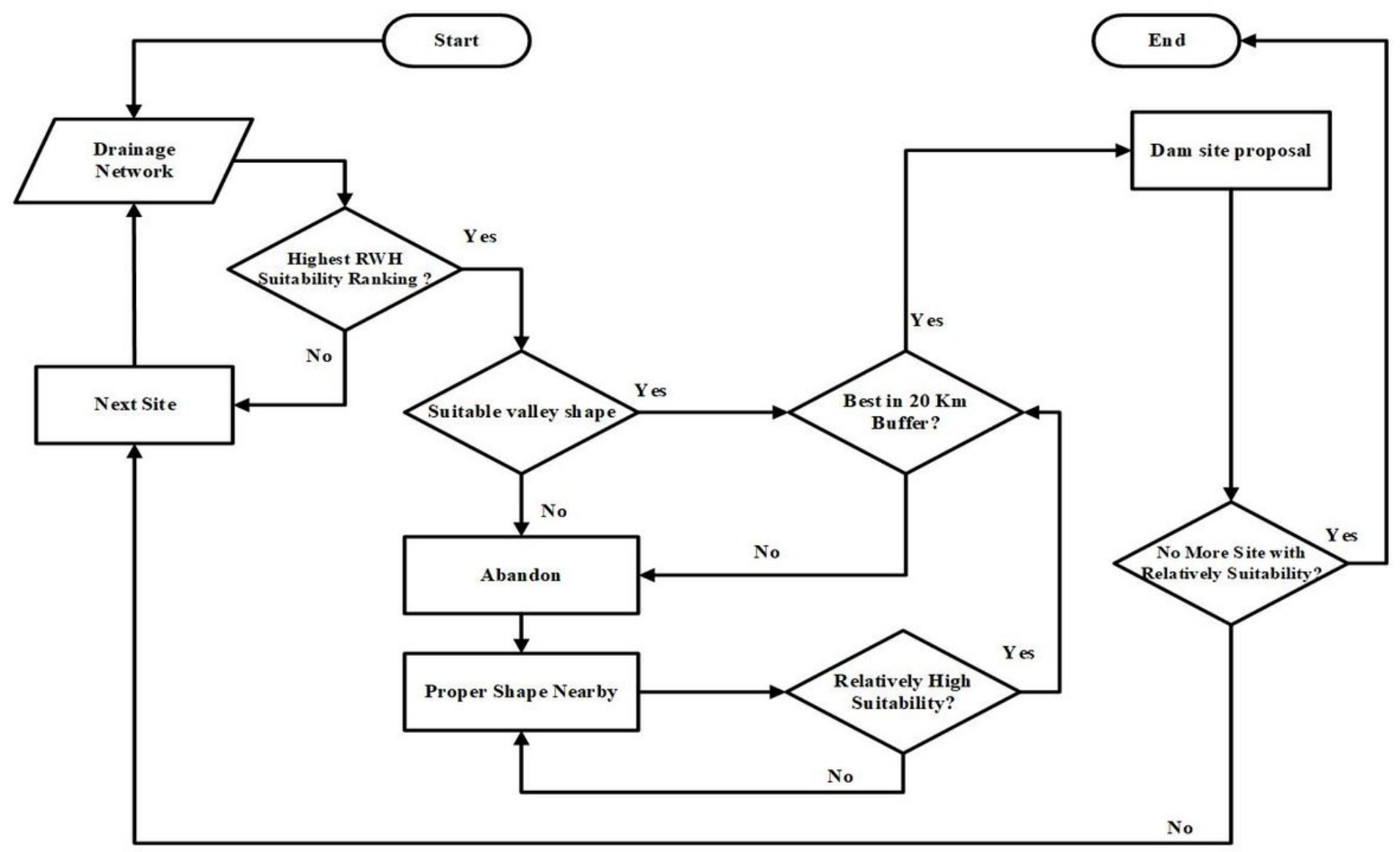

Figure 3

Flowchart of generating proposed dam sites 


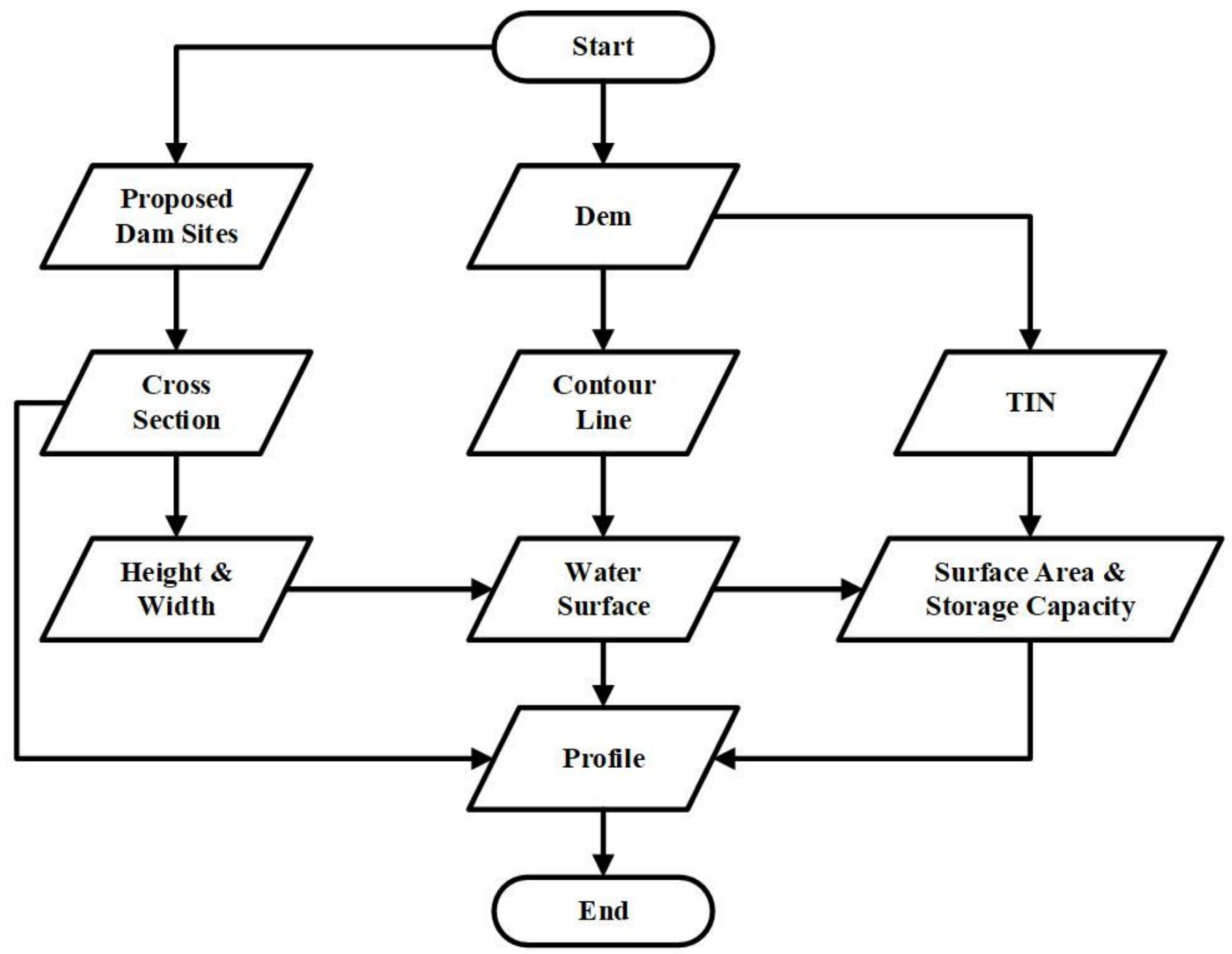

Figure 4

Flowchart of dam sites profiles generation 

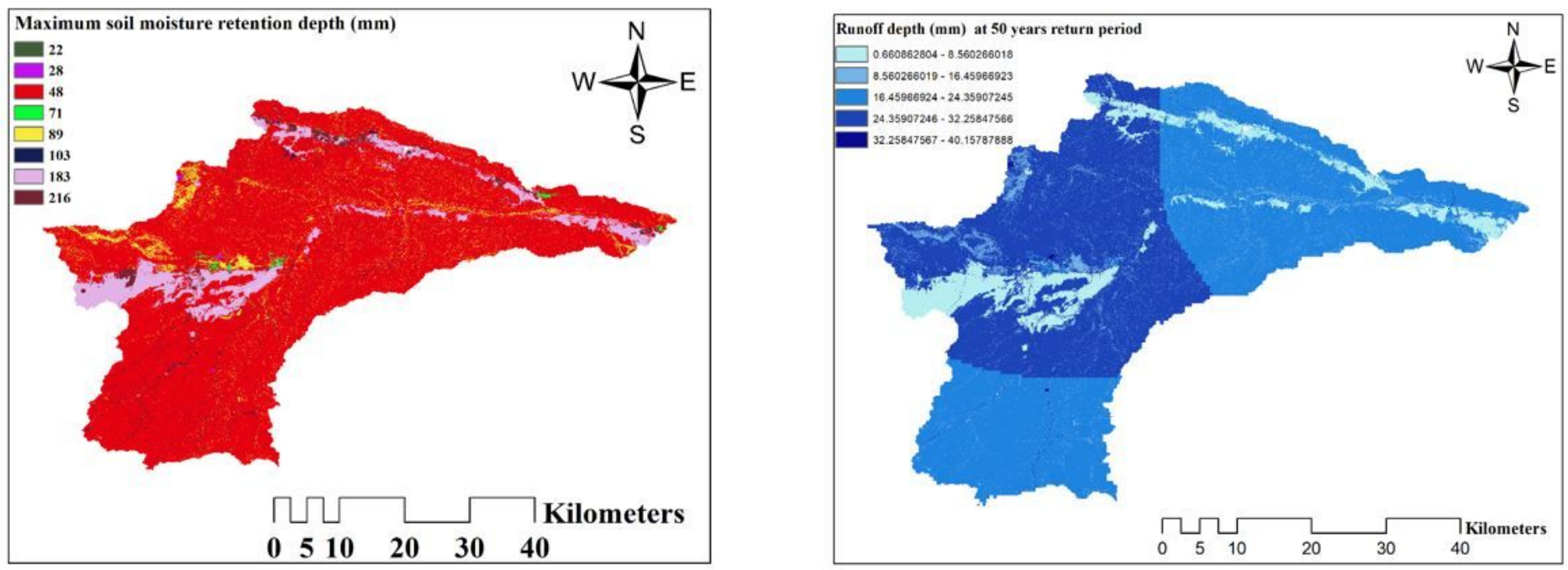

A

B

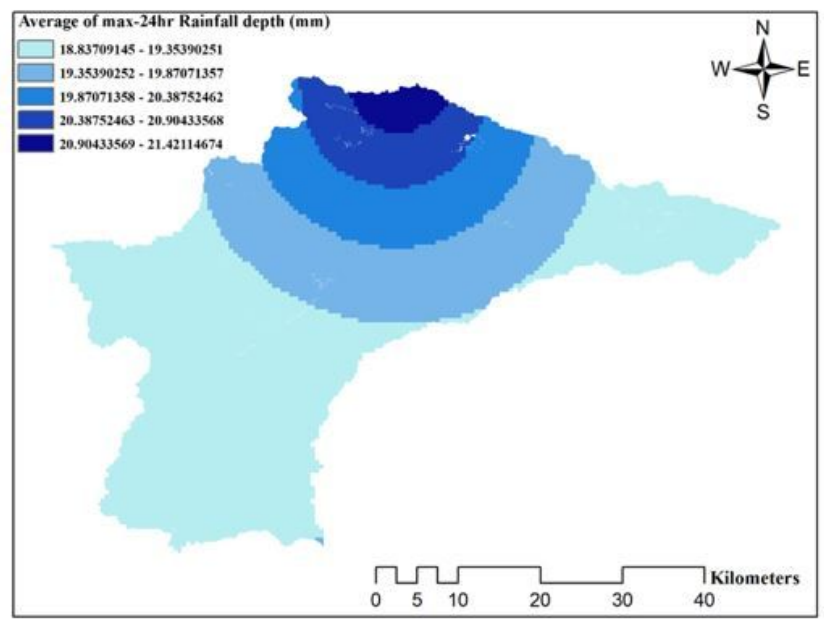

$\mathrm{c}$

Figure 5

A) Maximum of soil moisture retention map, b) Potential Runoff depth at 50-years return period in Wadi Nisah c) Average of annual max-24hr rainfall map. 

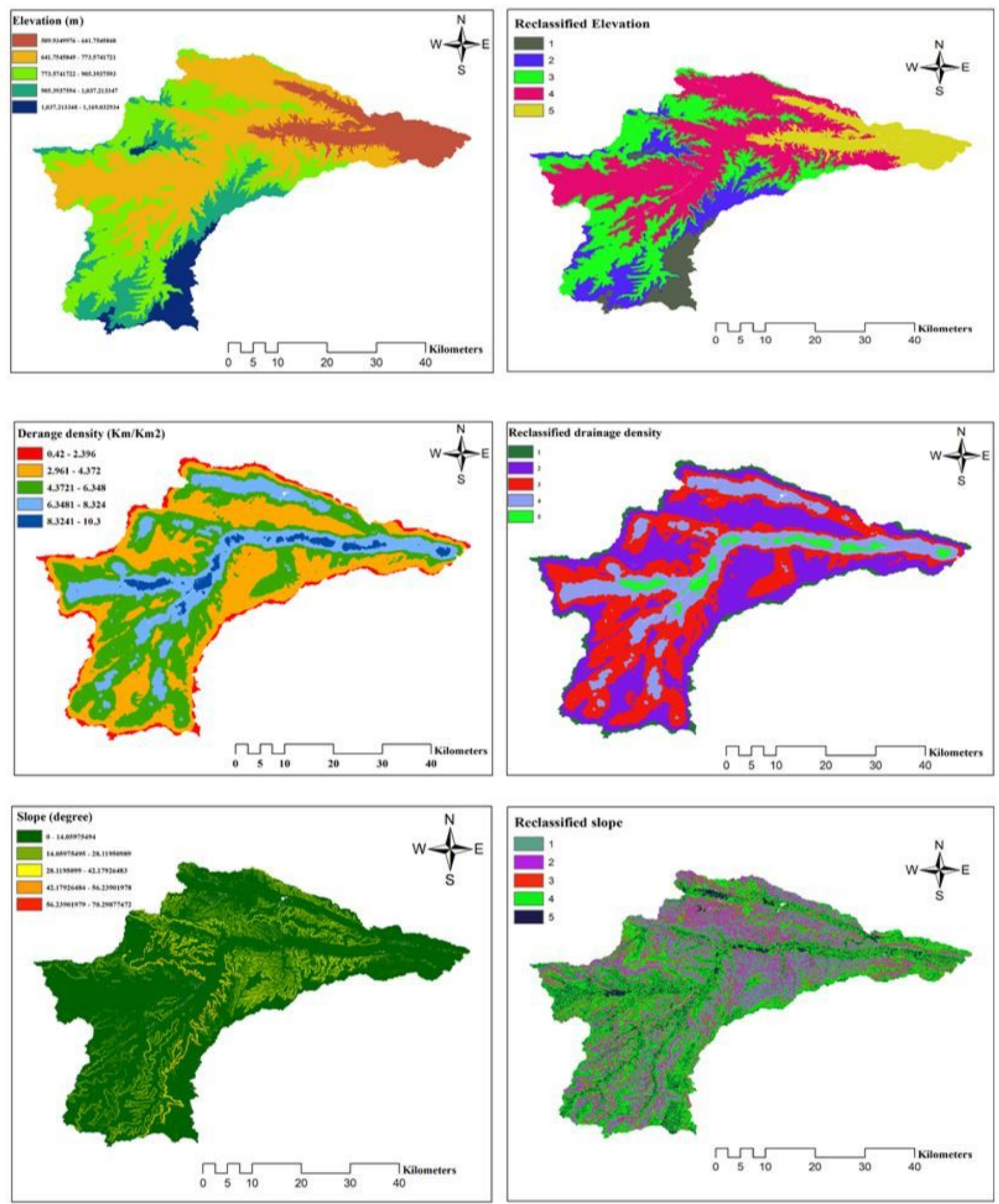

\section{Figure 6}

The criteria maps for AHP of flash flood hazard in Wadi Nisah. 

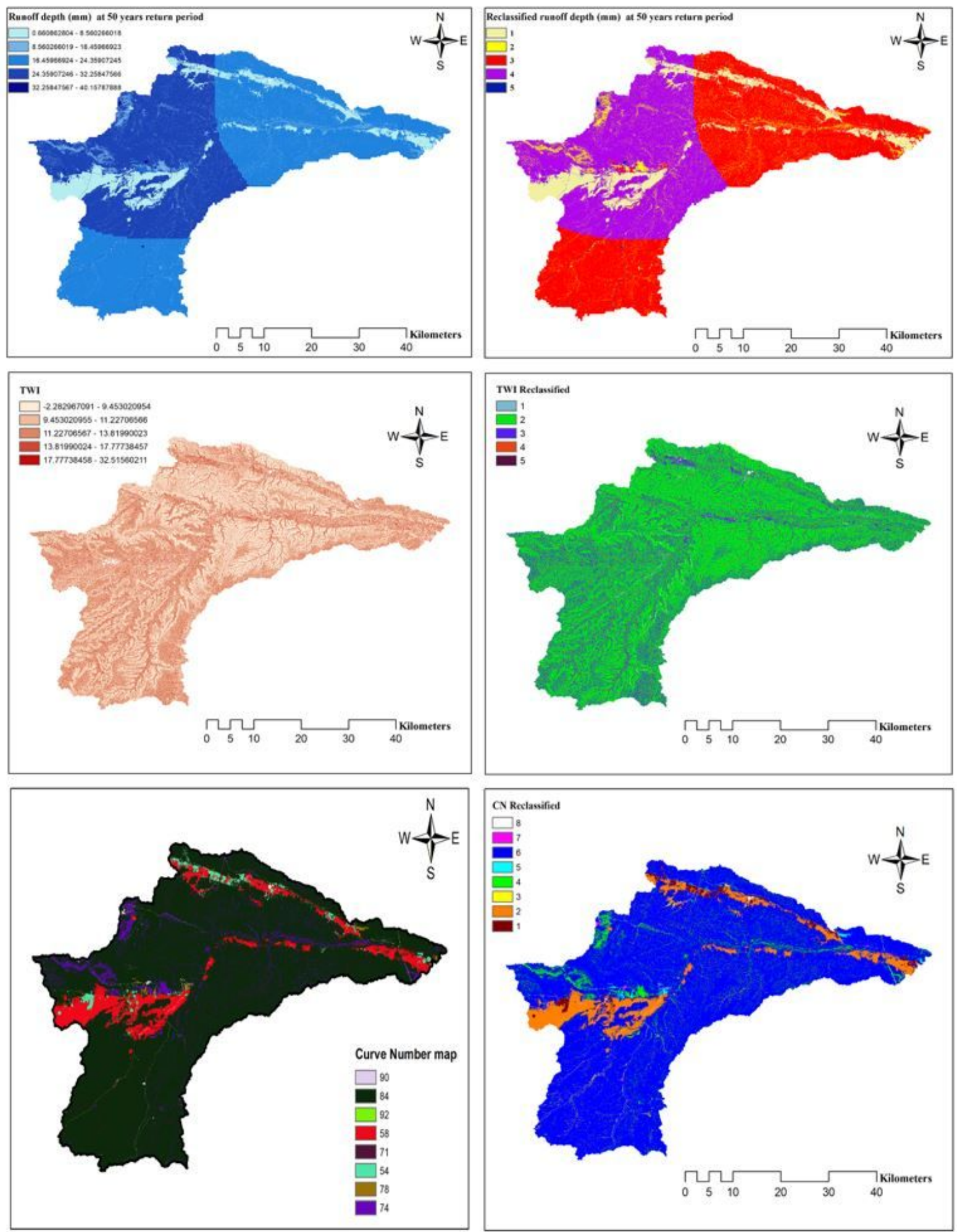

Figure 7

Flash flood hazard map for Wadi Nisah. 

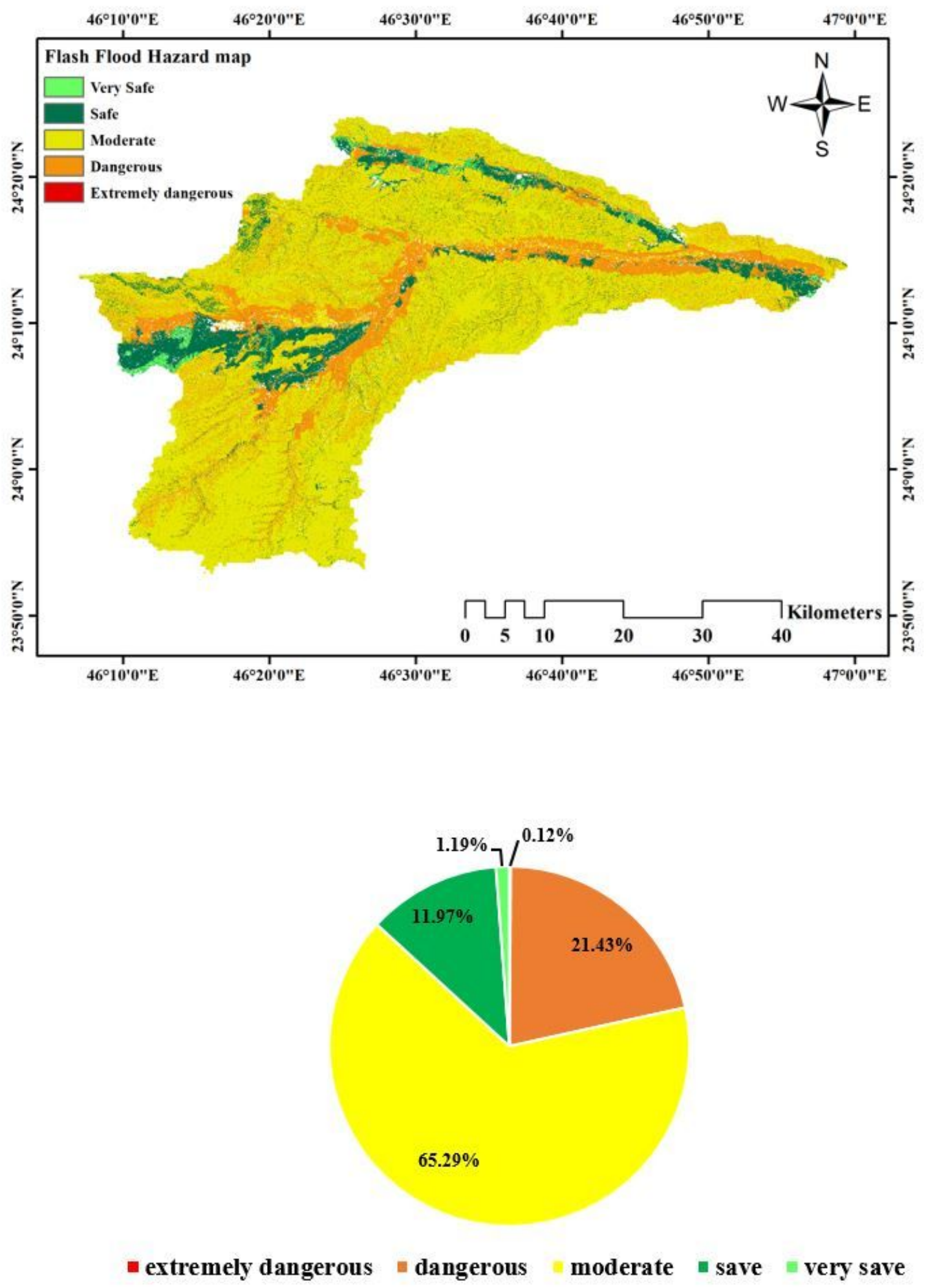

Figure 8

Percentage of area chart covered by different classes of flood Hazard in Wadi Nisah. 

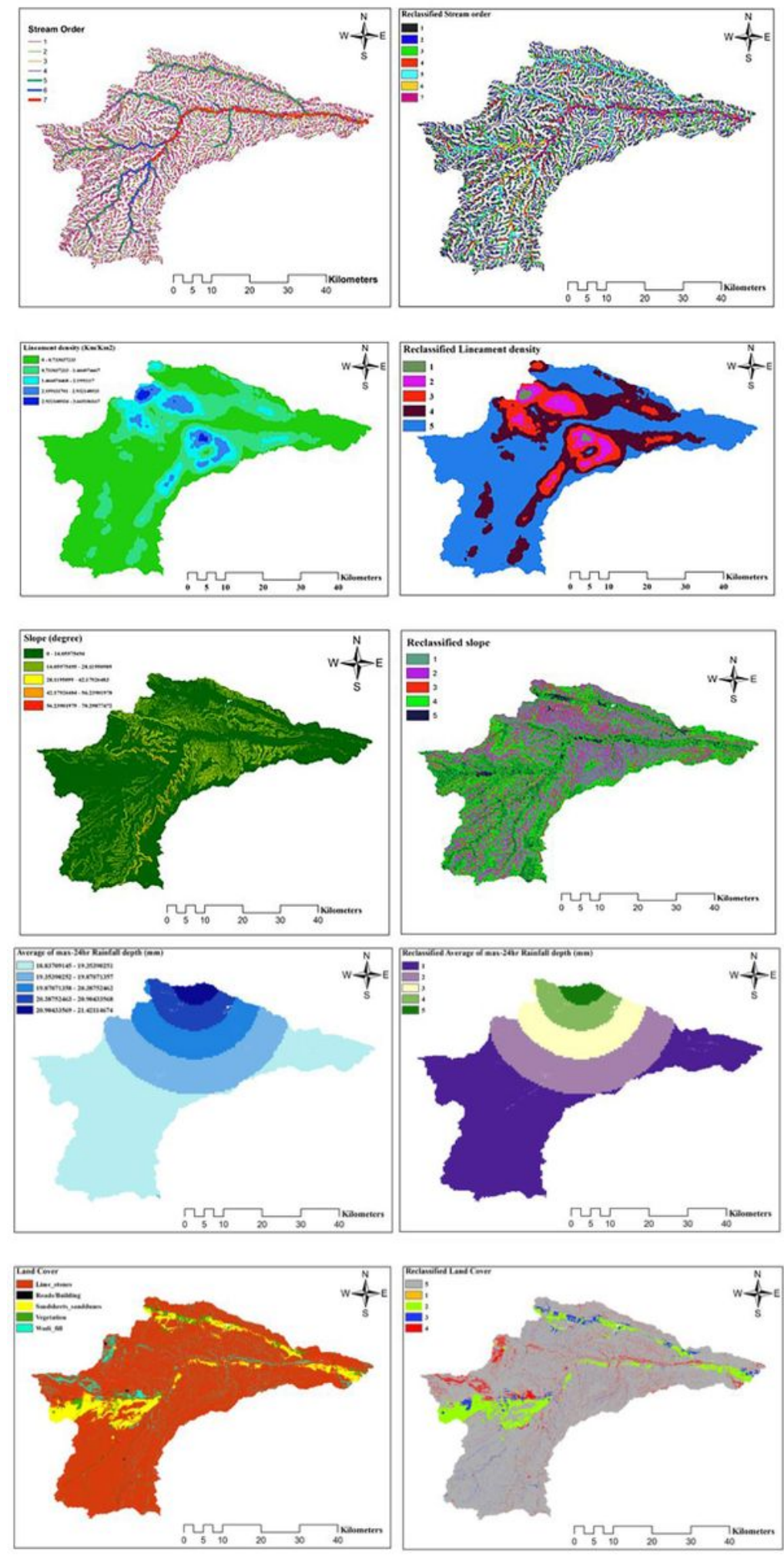

Figure 9

Criteria maps for AHP of Rainwater harvesting in Wadi Nisah. 


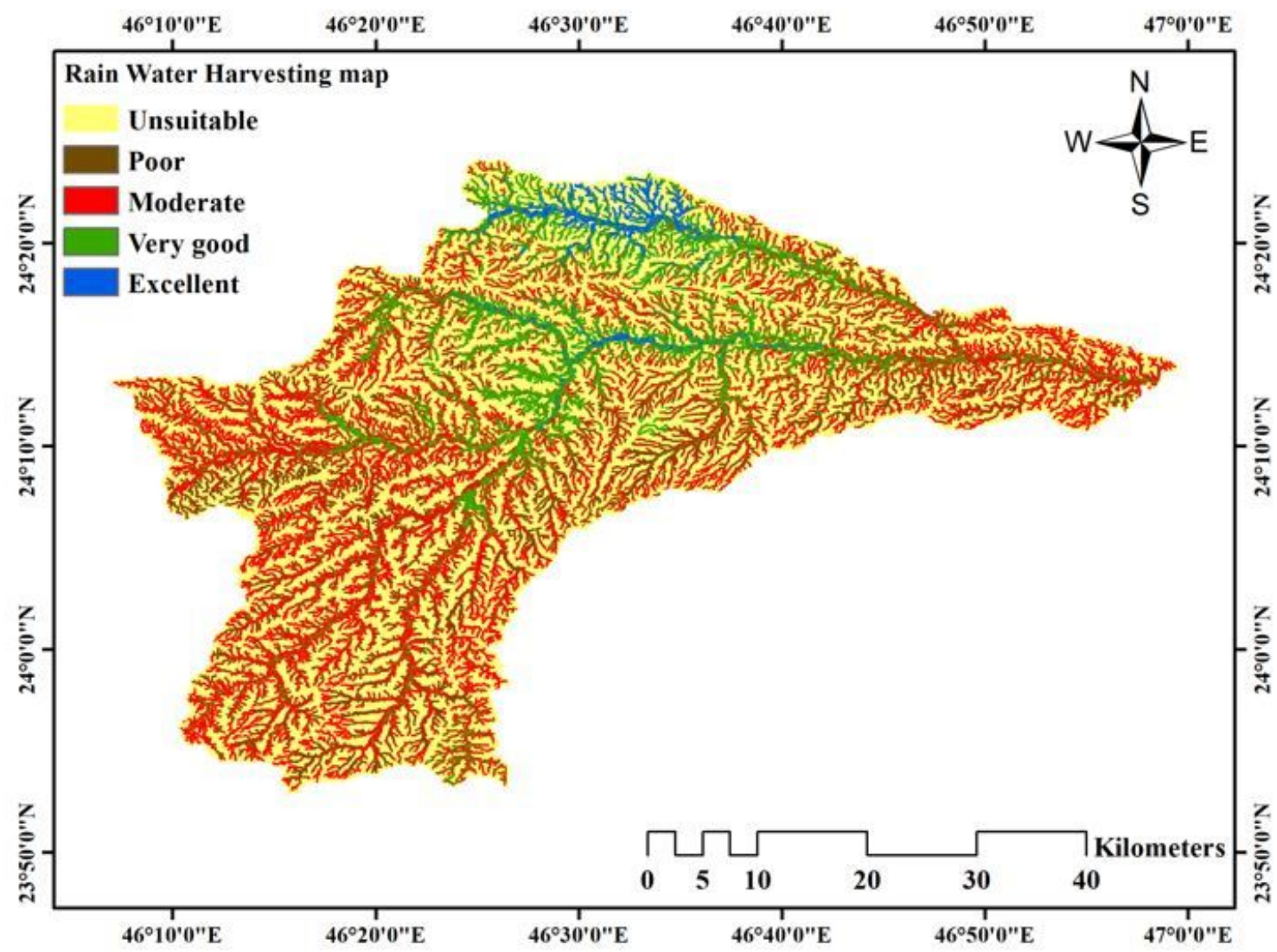

$1.71 \%$

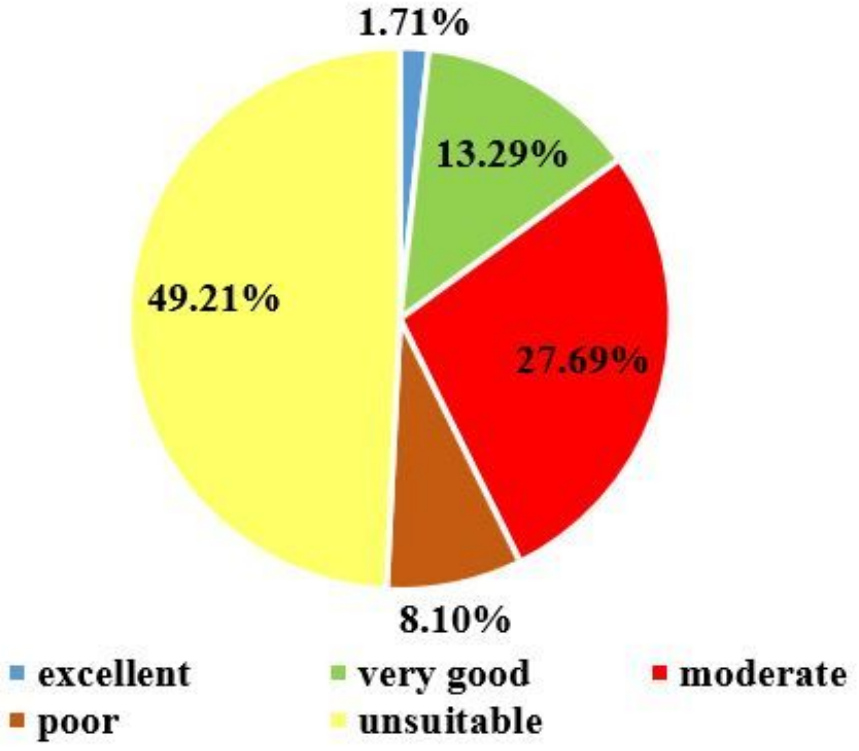

Figure 10

Percentage of area covered by different rainwater harvesting suitability in Wadi Nisah. 


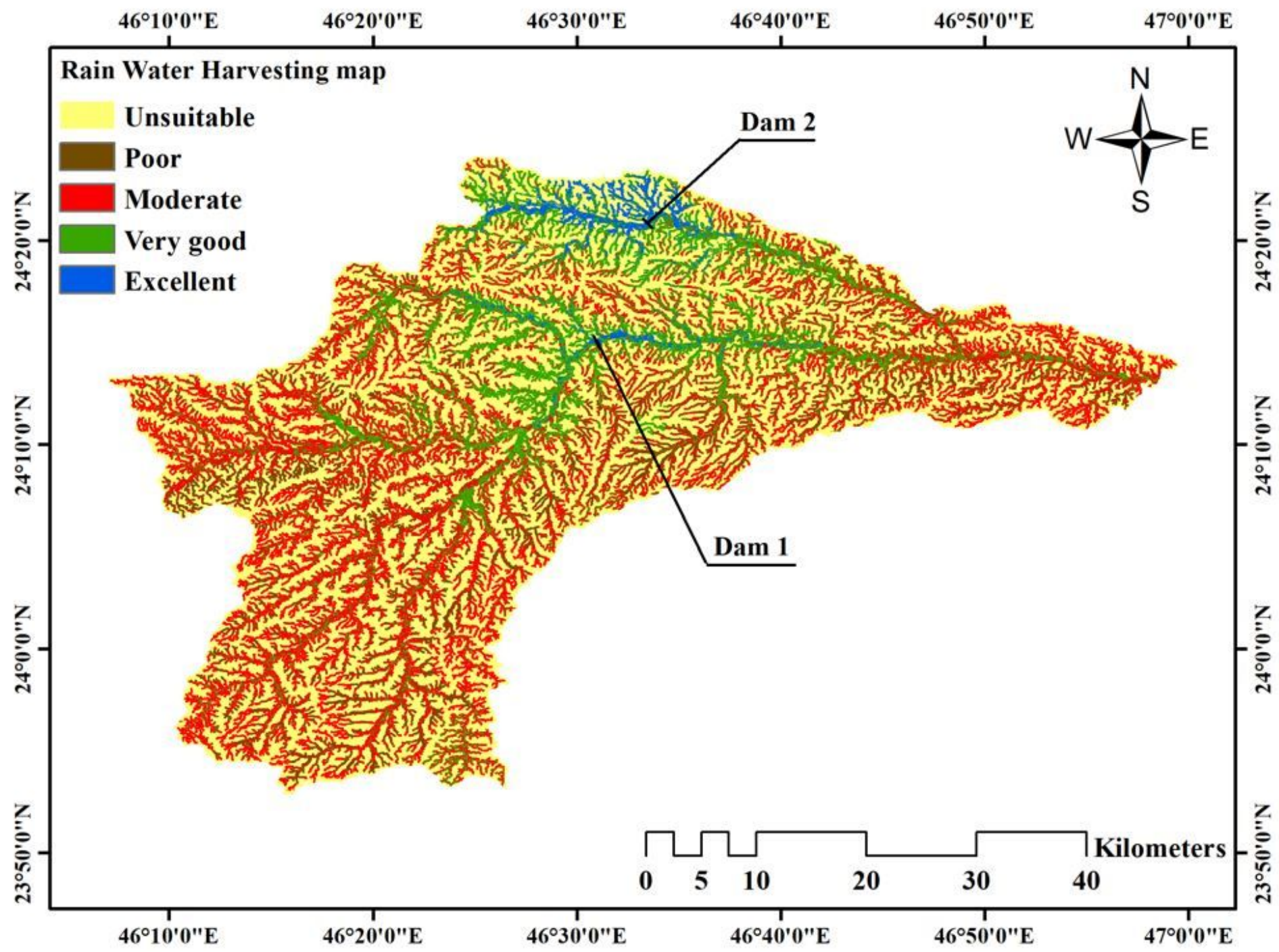

Figure 11

Location of two proposed dam sites with RWH map.in Wadi Nisah 
A
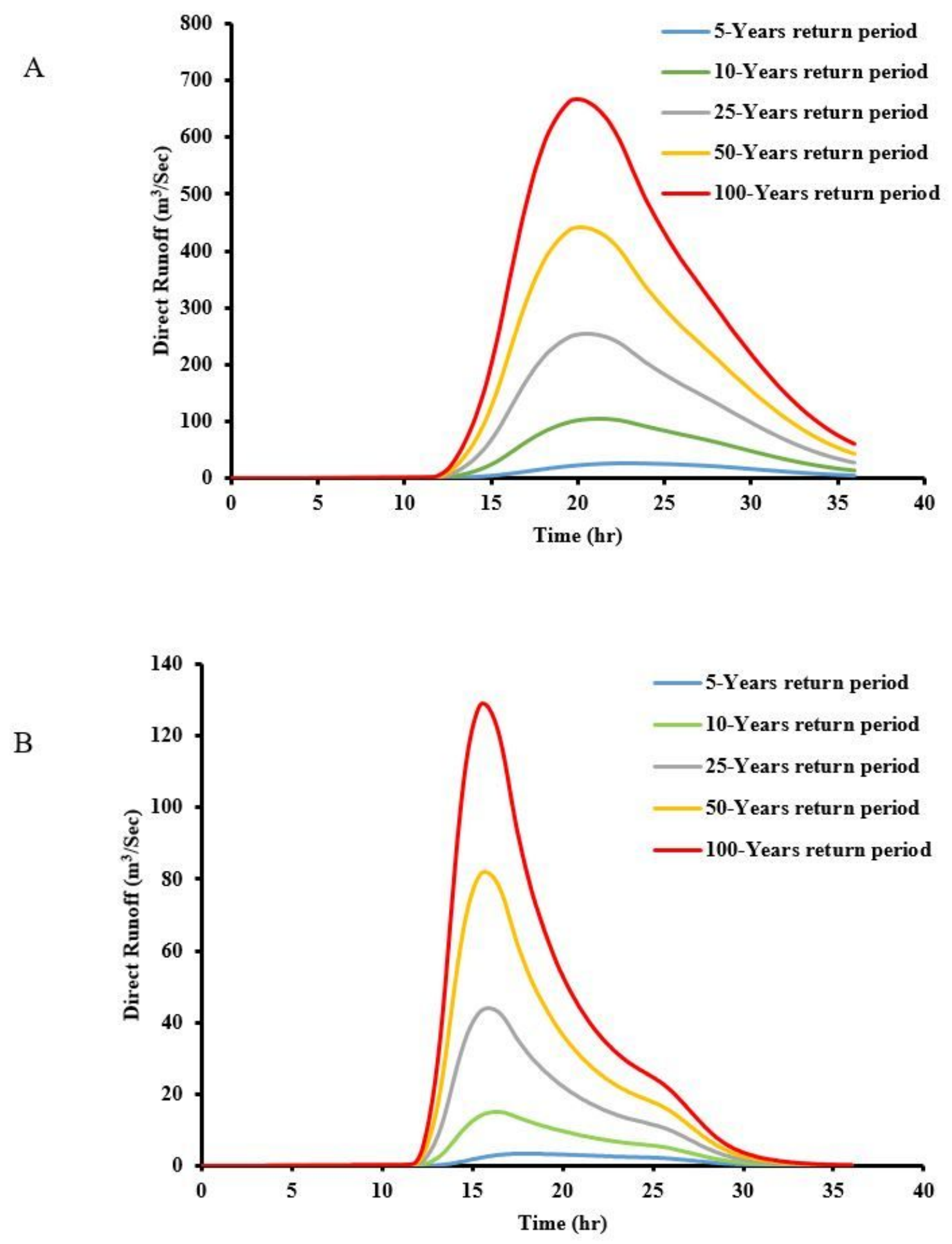

Figure 12

A) Hydrograph curve for Dam (1) at different return periods, B) Hydrograph curve for Dam (2) at different return periods. 


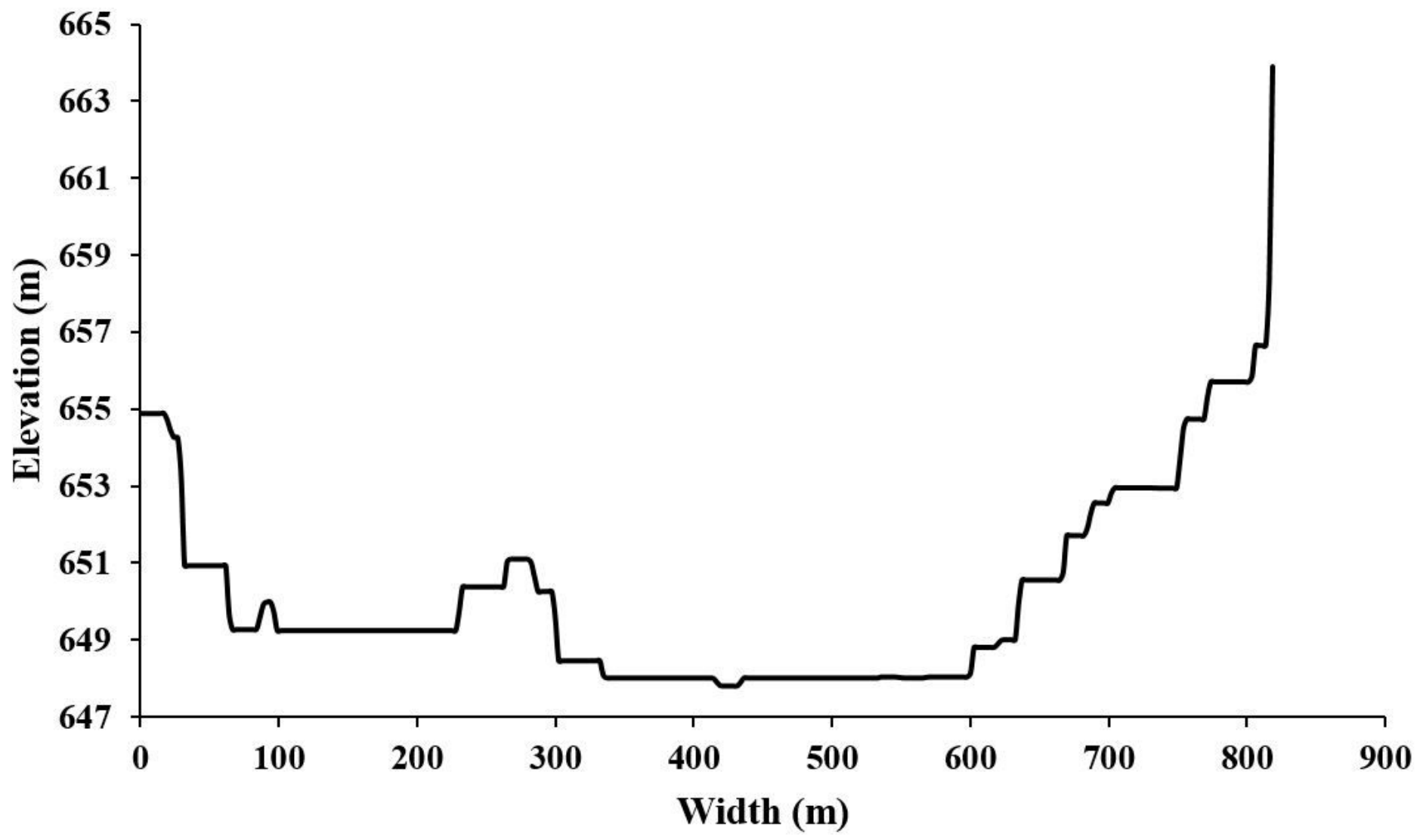

Figure 13

Cross section of proposed Dam 1. 


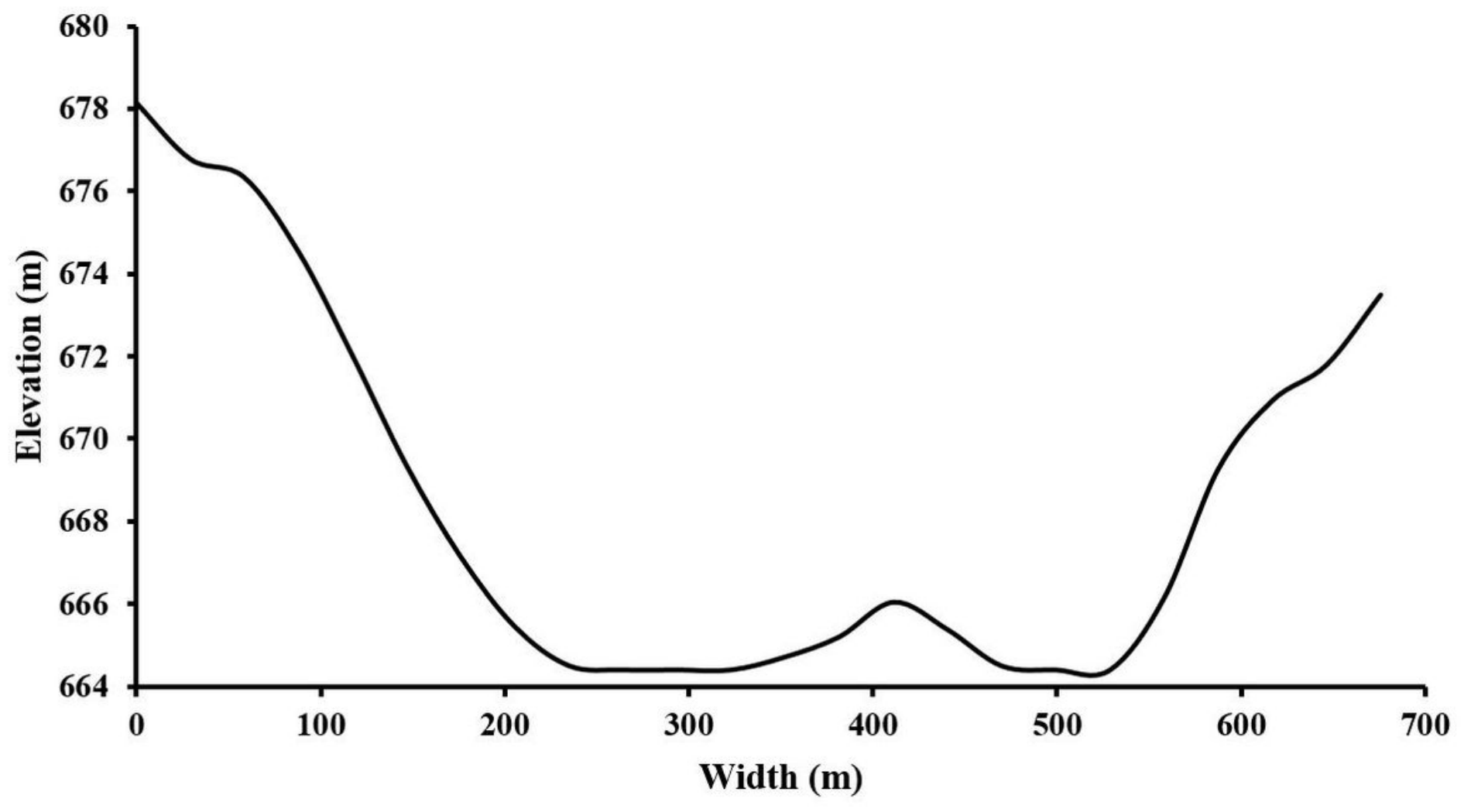

Figure 14

Cross section of proposed Dam 2. 